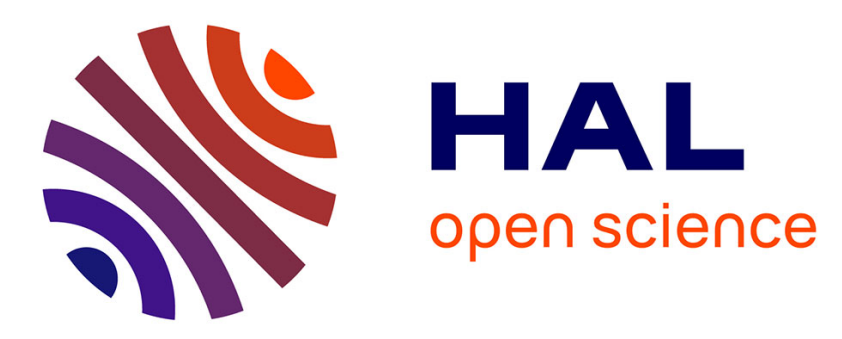

\title{
Large Sea Surface Temperature, Salinity, and Productivity-Preservation Changes Preceding the Onset of the Messinian Salinity Crisis in the Eastern Mediterranean Sea
}

Iuliana Vasiliev, Vasileios Karakitsios, Ioanna Bouloubassi, Konstantina Agiadi, George Kontakiotis, Assimina Antonarakou, Maria Triantaphyllou, Alexandra Gogou, Nefeli Kafousia, Marc de Rafélis, et al.

\section{- To cite this version:}

Iuliana Vasiliev, Vasileios Karakitsios, Ioanna Bouloubassi, Konstantina Agiadi, George Kontakiotis, et al.. Large Sea Surface Temperature, Salinity, and Productivity-Preservation Changes Preceding the Onset of the Messinian Salinity Crisis in the Eastern Mediterranean Sea. Paleoceanography and Paleoclimatology, 2019, 34 (2), pp.182-202. 10.1029/2018PA003438 . hal-02193260

\author{
HAL Id: hal-02193260 \\ https://hal.science/hal-02193260
}

Submitted on 8 Jul 2021

HAL is a multi-disciplinary open access archive for the deposit and dissemination of scientific research documents, whether they are published or not. The documents may come from teaching and research institutions in France or abroad, or from public or private research centers.

$$
\text { Copyright }
$$

L'archive ouverte pluridisciplinaire HAL, est destinée au dépôt et à la diffusion de documents scientifiques de niveau recherche, publiés ou non, émanant des établissements d'enseignement et de recherche français ou étrangers, des laboratoires publics ou privés. 


\section{Paleoceanography and Paleoclimatology}

\author{
RESEARCH ARTICLE \\ 10.1029/2018PA003438 \\ Key Points: \\ - Mediterranean Sea was significantly \\ saltier and colder between $6.415 \mathrm{Ma}$ \\ and $6.150 \mathrm{Ma}$, than between 6.150 \\ and $5.971 \mathrm{Ma}$ \\ - A salinity decrease at $6.150 \mathrm{Ma}$ \\ seems to be a fast event just \\ preceding the inception of a \\ warming phase lasting until the \\ MSC onset \\ - Paratethys contributed to increasing \\ freshwater supply from African \\ rivers leading to normal marine \\ Mediterranean between 6.150-5.971 \\ Ma
}

Supporting Information:

- Supporting Information S1

Correspondence to:

I. Vasiliev,

iuliana.vasiliev-popa@senckenberg.de; iuli.iuliana@yahoo.com

Citation:

Vasiliev, I., Karakitsios, V.,

Bouloubassi, I., Agiadi, K., Kontakiotis, G., Antonarakou, A., et al. (2019). Large sea surface temperature, salinity, and productivity-preservation changes preceding the onset of the Messinian Salinity Crisis in the eastern

Mediterranean Sea. Paleoceanography and Paleoclimatology, 34, 182-202. https://doi.org/10.1029/2018PA003438

Received 17 JUL 2018

Accepted 10 JAN 2019

Accepted article online 16 JAN 2019

Published online 9 FEB 2019

(C)2019. American Geophysical Union. All Rights Reserved.
Large Sea Surface Temperature, Salinity, and ProductivityPreservation Changes Preceding the Onset of the Messinian Salinity Crisis in the Eastern Mediterranean Sea

\author{
Iuliana Vasiliev $^{1}$ (D), Vasileios Karakitsios ${ }^{2}$, Ioanna Bouloubassi ${ }^{3}$, Konstantina Agiadi $^{2}$ (D), \\ George Kontakiotis $^{2}$ (D, Assimina Antonarakou ${ }^{2}$ (D), Maria Triantaphyllou ${ }^{2}$, Alexandra Gogou ${ }^{4}$ (D), \\ Nefeli Kafousia ${ }^{2}$ (D), Marc de Rafélis ${ }^{5}$, Stergios Zarkogiannis ${ }^{2}$ (D), Fanny Kaczmar ${ }^{3}$, \\ Constantine Parinos ${ }^{4}$ iD, and Nikolaos Pasadakis ${ }^{6}$
}

\begin{abstract}
${ }^{1}$ Senckenberg Biodiversity and Climate Research Centre BiK-F, Frankfurt am Main, Germany, ${ }^{2}$ Faculty of Geology and Geoenvironment, National and Kapodistrian University of Athens, Athens, Greece, ${ }^{3}$ LOCEAN-IPSL, UMR 7159, CNRS/IRD/UPMC/MNHN, Université Pierre et Marie Curie, Paris, France, ${ }^{4}$ Hellenic Centre of Marine Research, Institute of Oceanography, Anavyssos, Greece, ${ }^{5}$ Département de Biologie et Géosciences Gésciences Environnement Toulouse (GET) UMR 5563, Paul Sabatier University - Toulouse III, Toulouse, France, ${ }^{6}$ Hydrocarbons Chemistry and Technology Laboratory, School of Mineral Resources Engineering, Technical University of Crete, Chania, Greece
\end{abstract}

\begin{abstract}
The Messinian Salinity Crisis (MSC; 5.97-5.33 Ma) is an enigmatic episode of paleoceanographic change, when kilometer-thick evaporite units were deposited in the Mediterranean basin. Here we use geochemical (biomarker and isotope) data to reconstruct sea surface temperature, salinity, and productivity-preservation changes in the Mediterranean basin just before the MSC. The proxy data indicate that the Mediterranean Sea was significantly saltier and colder between 6.415 and 6.151 Ma, than between 6.151 and 5.971 Ma. Salinity decrease at 6.151 Ma seems to be a relatively fast event just preceding the inception of a warming phase that lasted almost uninterrupted until the MSC onset. The water exchange with the Paratethys could have caused, along with the African rivers, an increased freshwater supply, resulting in normal marine Mediterranean waters between 6.151 and $5.971 \mathrm{Ma}$, despite the severe restriction of marine connections with the Atlantic at that time. Sea surface temperature changes determined a sharp drop in productivity and/or preservation of organic matter, marked by deposition of calcareous marls. Productivity and preservation were relatively high and constant until 6.01 Ma. Afterward, increased influx of terrestrial organic matter and probably enhanced water column stratification prevailed. Around 5.971 Ma, modifications in aquatic versus terrestrially derived biomarkers indicate changes in organic matter influx at the MSC onset.
\end{abstract}

Plain Language Summary More than five million years ago, the Mediterranean Sea underwent astonishing changes in its hydrological budget leading to the formation of hypersaline water bodies and the deposition of a more than 1,000-m salt giant. The way toward the hypersaline conditions of the Messinian Salinity Crisis (5.97-5.33 Ma) was marked by gradual closure of Mediterranean oceanic seaways. Data reveal that the Mediterranean Sea was $8 \%$ saltier and, in average, $1.2{ }^{\circ} \mathrm{C}$ colder between 6.415 and 6.151 Ma, than between 6.151 and 5.971 Ma. At 6.151 Ma, a salinity decrease from 47\%o toward normal marine of 39\% was a fast event just preceding the inception of a warming lasting almost uninterrupted until the Messinian Salinity Crisis onset.

\section{Introduction}

At the end of the Miocene, the Mediterranean Sea underwent astonishing changes in the long-term hydrological cycle leading to the formation of hypersaline water bodies and the deposition of a salt giant $(>1,000 \mathrm{~m}$ thick; Ryan, 2009). This event, called the Messinian Salinity Crisis (MSC; 5.97-5.33 Ma), resulted from the restriction of the Mediterranean's connections with the Atlantic Ocean to the west and the freshwater Paratethys basins in the northeast (Figure 1; Krijgsman et al., 1999). Multidisciplinary studies have led to a three-stage model for the MSC, with gypsum precipitation in shallow subbasins during stage 1 (5.97-5.6 Ma), halite precipitation in the deepest depocenters during stage 2 (5.6-5.55 Ma), and large-scale 


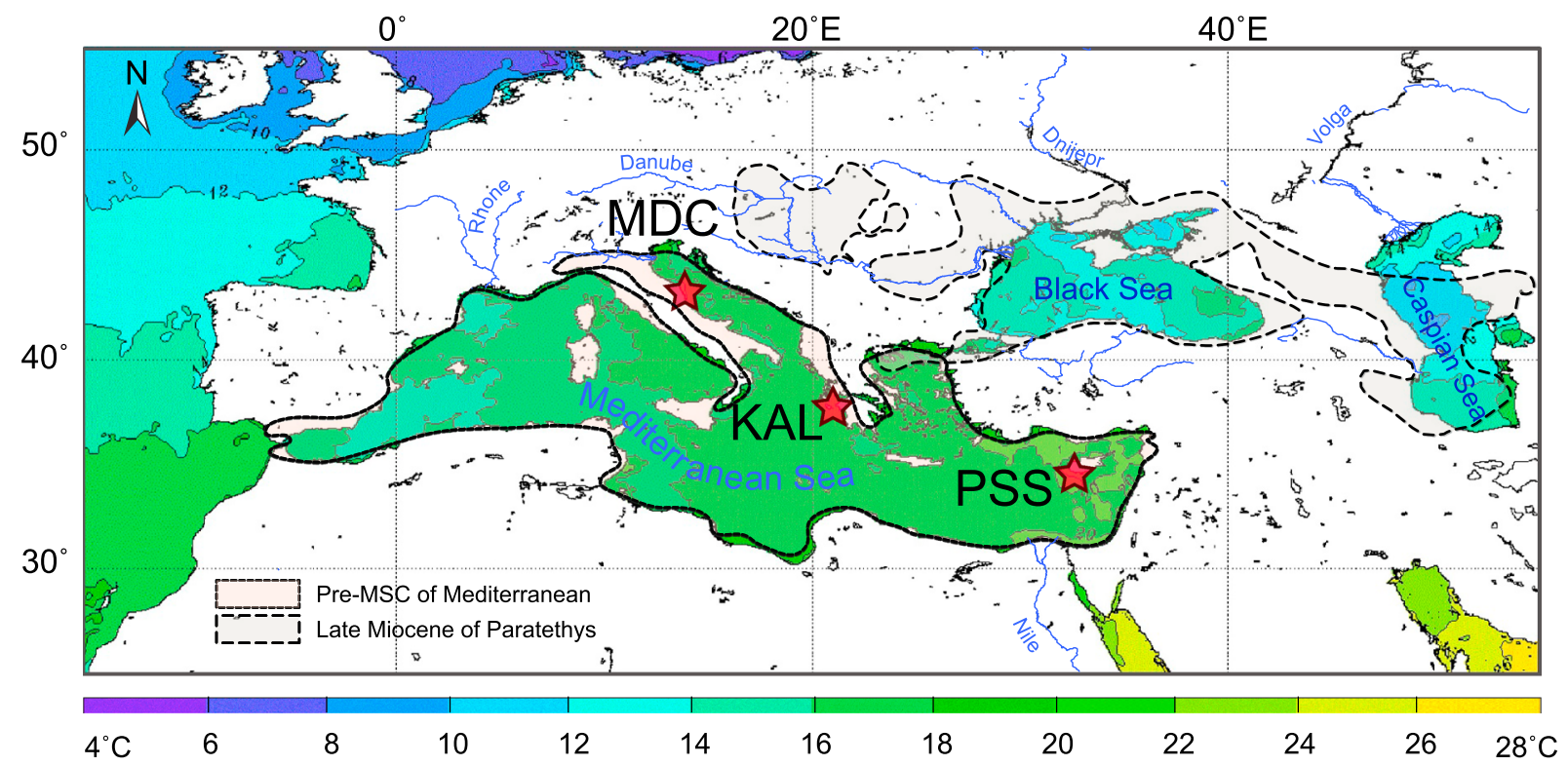

Figure 1. Location of Kalamaki (KAL) section. Modern sea surface temperatures are shown according to the World Ocean Atlas (NOOA, 2005). MDC and PSS denote the locations of Monte dei Corvi (Italy) and Pissouri south (Cyprus) sections, respectively. The former Mediterranean and Paratethys domains are outlined. MSC $=$ Messinian Salinity Crisis.

environmental fluctuations that transformed the Mediterranean into a brackish-water domain during stage 3 (5.55-5.33 Ma; Roveri et al., 2014).

The original definition of the MSC referred to a marked environmental change at the base of the Tripoli diatomite formation close to Tortonian/Messinian boundary (Selli, 1960). Restricted environmental conditions started well before MSC, as has long been known from deposition of diatomites and black shales and associated faunal and isotopic changes in the early Messinian (e.g., Cita, 1976). Causal mechanisms in the restriction history of the Mediterranean were tectonic movements due to the gradual closure of the Betic (7.2 Ma; Flecker et al., 2015), South Rif (6.64-6.44 Ma; Ivanovic et al., 2013), and North Rif marine corridors (7.35 Ma; Tulbure et al., 2017; or before 6.1 Ma; Achalhi et al., 2016). Salinity increase preceding the MSC was difficult to prove, but it has been inferred to start as early as $~ 6.8-6.7$ Ma in surface waters (e.g., Bellanca et al., 2001; Santarelli et al., 1998) and perhaps even as early as 7.167 Ma in the bottom-water environments of the deepest Mediterranean basins (e.g., Kouwenhoven et al., 2003). Rapidly changing surface-water paleoenvironments, leading to oligotypic assemblages, scarcity of calcareous nannofossils, and eventually to a-planktonic zones in foraminifera record, may in part be explained by periodically enhanced salinity (Kouwenhoven \& van der Zwaan, 2006). Finally, astronomical tuning of the pre-evaporitic succession showed that the MSC onset was synchronous throughout the Mediterranean (e.g., Krijgsman et al., 1999; Manzi et al., 2018; Meilijson et al., 2018). However, the salinity changes accompanying the way into the MSC are still under debate. Decreasing abundances of Mediterranean planktonic assemblages and a trend toward low diversity are attributed to increasingly adverse conditions of the surface waters preceding the onset of the MSC. These adverse conditions are to be related to oxygenation of water column and salinity, the latter being constrained only by the $\sim 50 \mathrm{~g} / \mathrm{L}$ the upper tolerance limit of foraminifera (Flecker et al., 2015). This contribution is intended to understand how warm, salty, and prolific for marine life the Eastern Mediterranean basin was just before the onset of the MSC.

In the past decade, several studies focused on understanding the evolution of the Late Miocene Mediterranean-Atlantic gateways and their regional and global impacts (e.g., Flecker et al., 2015; Marzocchi et al., 2015; Simon et al., 2017; Simon \& Meijer, 2017). It was shown that the Mediterranean's hydrologic budget is controlled by both the efficiency of the gateway(s) and net evaporation over the Mediterranean (Flecker et al., 2015). A relatively wide corridor of $15 \mathrm{~km}$ would still need to shallow by at least $20 \mathrm{~m}$ to raise the basin salinity from present-day values to about $50 \mathrm{~g} / \mathrm{L}$ (Simon et al., 2017). The next logical step would require that the modeling experiments are supported by quantitative 
proxy data. Progresses in the application of organic geochemistry-based proxies offer novel tools for unraveling fundamental paleoenvironmental parameters. However, only a limited number of studies have used organic geochemistry proxies for the pre-MSC and MSC intervals (Sinninghe Damsté et al., 1995; Andersen et al., 2001; Tzanova et al., 2015; Herbert et al., 2016; Mayser et al., 2017; Natalicchio et al., 2017; Vasiliev et al., 2017).

Late Miocene sea surface temperature (SST) records are sparse, and only one deals with the Mediterranean (Tzanova et al., 2015). Foraminifera stable oxygen isotope and $\mathrm{Mg} / \mathrm{Ca}$ proxies suffer from biases (preservation, diagenesis, and salinity) in the Mediterranean realm, which render them insufficient for SST reconstructions (Antonarakou, Kontakiotis, Zarkogiannis, et al., 2018, Antonarakou, Kontakiotis, Vasilatos, et al., 2018; Kontakiotis et al., 2011, Kontakiotis, Mortyn, et al., 2016, Kontakiotis et al., 2017). Alkenone paleothermometry $\left(\mathrm{U}^{K^{\prime}}{ }_{37}\right.$-index-based SST) appears more suitable/less biased in the Mediterranean Sea (Herbert et al., 2016) although those alkenones were produced by extinct species of haptophytes (Athanasiou et al., 2017; Herbert et al., 2015; Tzanova et al., 2015).

Here we present the first record of alkenone-derived SST in the eastern Mediterranean Sea for the time interval preceding the MSC onset (6.45-5.97 Ma). Our $\mathrm{U}^{K^{\prime}}{ }_{37}$-based SSTs extend the $\mathrm{U}^{K^{\prime}}{ }_{37}$-SST data set from the Monte dei Corvi section (Figure 1; 13.0-6.4 Ma; Tzanova et al., 2015). We further use the alkenone-based SST in conjunction with available $\delta^{18} \mathrm{O}$ planktonic foraminiferal data (Karakitsios, Cornée, et al., 2017; Karakitsios, Roveri, et al., 2017) to reconstruct sea surface salinity (SSS). Abundances of lipid biomarkers from primarily planktonic sources (alkenones, sterols, diols, ketols, and archaeol) and higher plant waxes (long chain $n$-alkanes) are used to describe variations in algal production (and preservation) and the continentally derived, organic matter supply. The data are discussed in view of the available paleoenvironmental studies (e.g., Flecker et al., 2015; Herbert et al., 2016; Mayser et al., 2017; Moissette et al., 2018; Tzanova et al., 2015) pinning down the paleoenvironmental conditions prevailing in the eastern Mediterranean Sea just before the MSC. This research delivers the first reconstructed SST and SSS estimates to be used for validating models of the Mediterranean Sea water (ex)changes during the MSC onset.

\section{Geological Setting and Chronostratigraphic Framework}

The study focused on Kalamaki section located on Zakynthos Island (37 $44011.95^{\prime \prime} \mathrm{N}, 20^{\circ} 54013.14^{\prime \prime} \mathrm{E}$; Figures 1 and 2). Early Miocene-Late Pleistocene deposits are exposed along the sections created by the NW-SE reverse faulting (Underhill, 1989). Kalamaki section has been subject to dating using planktonic foraminifera and calcareous nannoplankton bioevents coupled to magnetostratigraphy and astronomical tuning (Figures 3 and 4; Karakitsios, Cornée, et al., 2017; Karakitsios, Roveri, et al., 2017). The pre-MSC Kalamaki is a 22.23 -m-long section (6.457-5.97 Ma) shortly overlapping with the MSC (up to $22.7 \mathrm{~m}$; $\sim 5.965 \mathrm{Ma}$ ). The section starts with calcareous marls and continues with alternations of laminated and massive marls (0-9 m; 6.457-6.128 Ma). The middle part of the section (9-14.7 m; 6.128-6.01 Ma) consists of laminated marls (9-11.5 m), followed by massive marls (11.5-14.7 m), including three calcareous marl beds and a thin laminated layered at $\sim 12.8 \mathrm{~m}$. The upper part of the section (14.7-22.23 m; 6.01-5.97 Ma) starts with a slump interval up to $17.7 \mathrm{~m}$ and is followed by massive marls with carbonate lenses. The uppermost age boundary of the section is at $\sim 5.965 \mathrm{Ma}$ assuming that the first gypsum (at $22.23 \mathrm{~m}$ ) is the first evaporite, marking the MSC onset (5.971 Ma; Manzi et al., 2013).

Based on these well-dated intervals, we estimated the ages of the used samples (Tables S1 and S2). The ages of the samples located close to or at bioevents are well constrained, whereas those in-between are estimated assuming a constant accumulation rate for the interval bracketed by the well-dated bioevents (Karakitsios, Cornée, et al., 2017; Karakitsios, Roveri, et al., 2017). The accumulation rate was different in the three parts of the section (Figure 3). In particular, the accumulation rate was $28 \mathrm{~cm} / \mathrm{kyr}$ in the lower part (0-9 $\mathrm{m} ; 6.457-$ $6.128 \mathrm{Ma}$ ), increased by more than $50 \%$ in the middle part (9-14.7 m; 6.128-6.01 Ma) reaching $44.5 \mathrm{~cm} / \mathrm{kyr}$, and then further to $209.5 \mathrm{~cm} / \mathrm{kyr}$ in the upper part (14.7-22.23 m; 6.01-5.971 Ma). We favor the hypothesis that the slump interval (4-m thickness) represents a short-time event and subtracting it makes the accumulation rate in the order of $100 \mathrm{~cm} / \mathrm{kyr}$, a value that is more than twice the sedimentation rate of the underlying interval, which seems possible. 


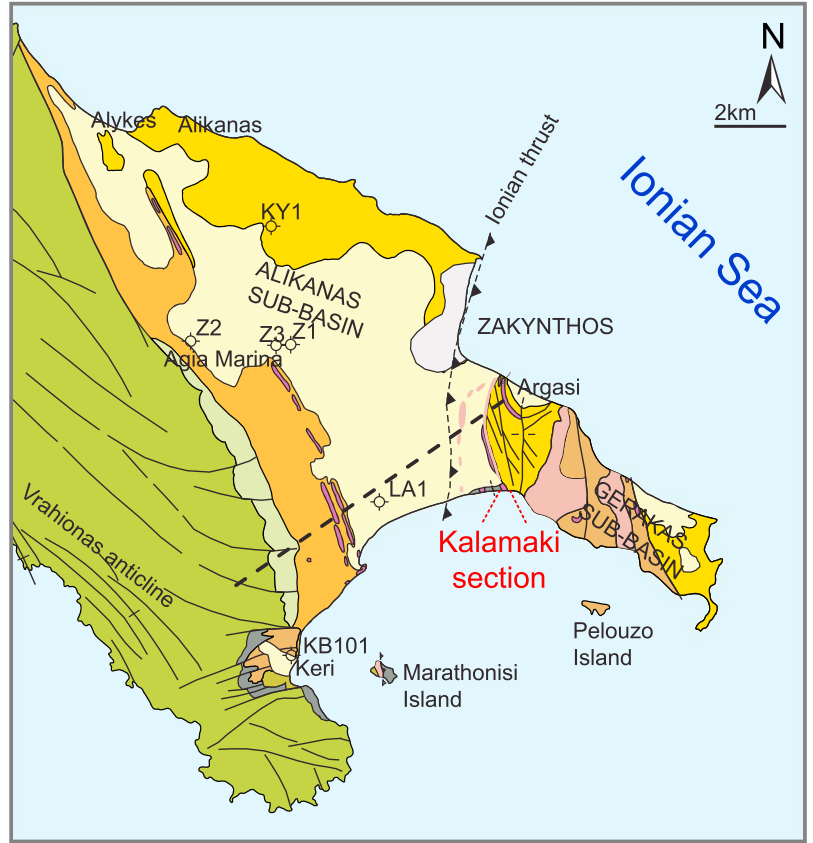

\section{Legend}

Quaternary (Q)

Pliocene-Pleistocene (P-PI)

$\square$ Lower Pliocene (LP)

$\square$ Messinian gypsum (Mg)

Upper Miocene (UM)

Lower Miocene (LM)

Cretaceous-Oligocene (C-O) Pre-Apulian

Ionian-Pre-Apulian transitional

Ionian Triassic breccias and gypsum (Tr)

Zakynyhos city

- borehole

fault

A thrust

' section under

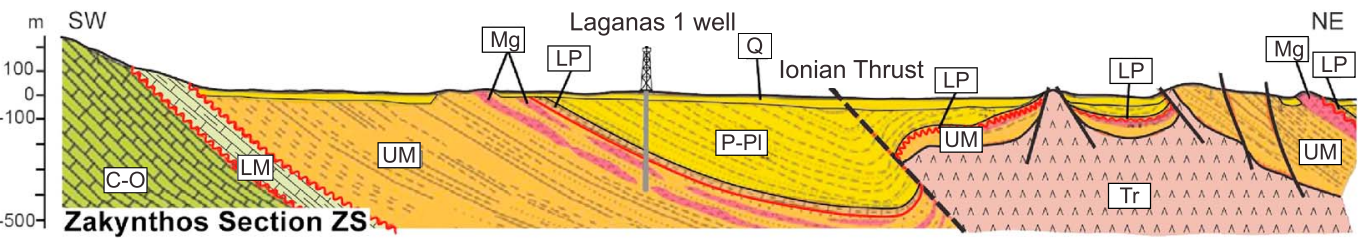

Figure 2. Geological map of Zakynthos Island and onshore Zakynthos section (modified after Karakitsios, Roveri, et al., 2017). Boreholes: Z1 (Zakynthos-1); Z2 (Zakynthos-2), Z3 (Zakynthos-3); LA1 (Laganas-1); KB101 (Keri-well), AK1 (Agios Kyrikos-1), KY1 (Kypseli-1) were used for correlation and structural control of the area.

\section{Experimental Methods}

\subsection{Lipid Extraction, Separation, and Analyses}

Lipid analyses were performed at the Laboratory of Oceanography and Climate, Université Pierre et Marie Curie, Paris and at the Hellenic Centre for Marine Research (Greece). In total, 29 rock samples were dried and crushed to a fine powder. Lipids were then extracted by ultrasonication (three times) using a solvent mixture of dichloromethane/methanol $(4: 1, v / v)$. The resulting total lipid extracs were separated into hydrocarbon, ketone, and alcohol/sterol fractions by open silica gel (500 mg) column chromatography with solvent mixtures of increasing polarity (hexane, hexane/ethyl acetate [95:5, v/v] plus, hexane/ethyl acetate [1:1], and hexane/ethyl acetate [70:30, $v / v]$, respectively). All fractions were analyzed by gas chromatography (GC) on a gas chromatograph (Agilent 6890 Plus) equipped with a flame ionization detector and fitted with a fused silica capillary column (DB-5MS, $30 \mathrm{~m}$, i.d.: $0.32 \mathrm{~mm}$, film thickness $=0.25 \mu \mathrm{m}$ ) with helium as carrier gas at $1.2 \mathrm{ml} / \mathrm{min}$. The $\mathrm{GC}$ oven temperature program was $60-160^{\circ} \mathrm{C}$ at a rate of $25^{\circ} \mathrm{C} / \mathrm{min}$, then raised to $310{ }^{\circ} \mathrm{C}$ at a rate of $2{ }^{\circ} \mathrm{C} / \mathrm{min}$, and held at $310^{\circ} \mathrm{C}$ for $10 \mathrm{~min}$. The on-column injector operated at the oventrack mode of temperature, and the detector temperature was set to $320^{\circ} \mathrm{C}$. Alcohols/sterols were derivatized with N,O-bis (trimethylsilyl) trifluoracetamide to form trimethylsilyl ethers prior to GC analyses. For the fractions containing long-chain alkenones, a fused column was used (CPSil5CB, $50 \mathrm{~m}$, i.d.: $0.32 \mathrm{~mm}$, film thickness $=0.25 \mu \mathrm{m})$ in order to achieve good separation of the target compounds $\left(\mathrm{C}_{37: 3}\right.$ and $\mathrm{C}_{37: 2}$ alkenones). Lipid fractions were also analyzed through GC-mass spectrometry (GC-MS; Agilent 6890 GC coupled to Agilent $5973 \mathrm{~N}$ MSD, ionization energy $=70 \mathrm{eV}$, scanning mass range $=\mathrm{m} / \mathrm{z} 50-800$ at 3 scans/s, same capillary column and oven temperature program) in order to confirm the identity of individual compounds. The identification of lipids was achieved by interpretation of their mass spectra and comparison 


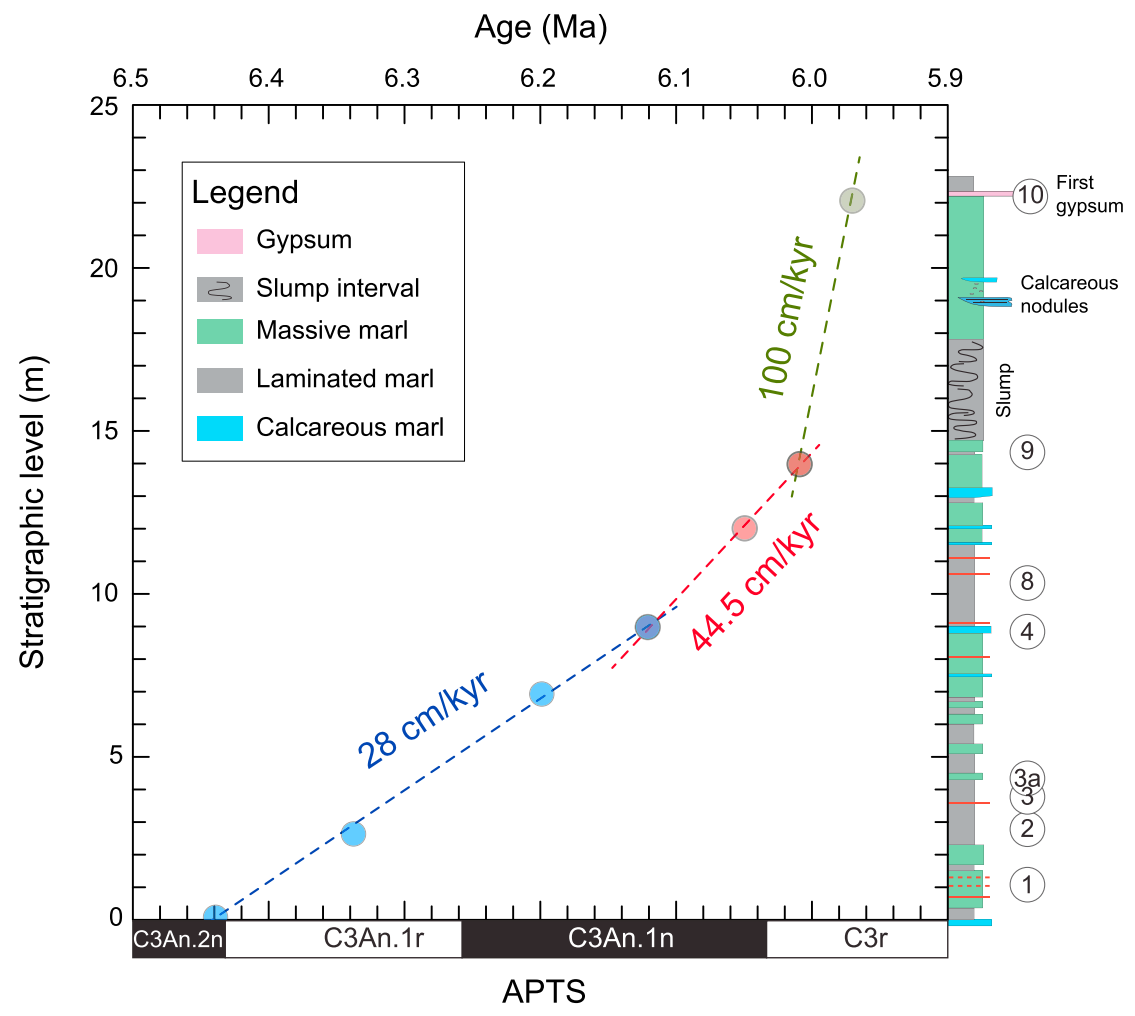

Figure 3. Accumulation rates for Kalamaki pre-Messinian Salinity Crisis section. The schematic lithological in on the right-hand side. The calculation had bioevents as time set points. The bioevents are placed in the figure 4 in the stratigraphic column. The differing accumulation rates are indicated with different colors, also used for plotting the total organic carbon values from intervals with different accumulation rates in Figure 5. APTS $=$ astronomically dated polarity timescale.

with literature data. Quantification was based on the GC-FID response relative to known amounts of internal standards (perdeuterated $n$-tetracosane, androstanol, and $n$-hexatriacontane).

\subsection{Temperature Estimates Based on Alkenones}

We used alkenones as a SST proxy, based on the assumption that the Reticulofenestra spp, found throughout the Kalamaki pre-MSC section (Karakitsios, Cornée, et al., 2017; Karakitsios, Roveri, et al., 2017) is the most probable alkenones producer (Athanasiou et al., 2017; Beltran et al., 2007, 2011) (Figure 4).

SST estimates were based on the degree of unsaturation of $\mathrm{C}_{37}$ alkenones $\left(\mathrm{U}^{K^{\prime}}{ }_{37}\right)$, which is primarily a function of temperature (Müller et al., 1998), by monitoring the ratio between the di- and tri-unsaturated alkenones, according to $U^{K^{\prime}}{ }_{37}=\mathrm{C}_{37: 2} /\left(\mathrm{C}_{37: 2}+\mathrm{C}_{37: 3}\right)$. We used the transfer function $\mathrm{U}^{K^{\prime}}{ }_{37}=0.033 \mathrm{~T}$ $\left[{ }^{\circ} \mathrm{C}\right]+0.044\left( \pm 1^{\circ} \mathrm{C}\right)$, based on a global core-top calibration of Müller et al. (1998). SST differences between replicate analyses were lower than $0.6^{\circ} \mathrm{C}$.

\subsection{Estimates of SSS}

Foraminiferal $\delta^{18} \mathrm{O}$ is a function of temperature and surface water $\delta^{18} \mathrm{O}\left(\delta^{18} \mathrm{O}_{\mathrm{sw}}\right)$, which depends on ice volume and salinity. Here we used the Turborotalita multiloba and Orbulina universa $\delta^{18} \mathrm{O}$ record of the Kalamaki pre-MSC section (Karakitsios, Cornée, et al., 2017; Karakitsios, Roveri, et al., 2017). To isolate the $\delta^{18} \mathrm{O}_{\mathrm{SW}}$, we removed the T-driven component using the $O$. universa $\left(\delta^{18} \mathrm{O}_{\mathrm{C}}\right)$ low-light paleotemperature equation of Bemis et al. (1998), $T=16.5-4.80 *\left(\delta^{18} \mathrm{O}_{\mathrm{C}}-\left[\delta^{18} \mathrm{O}_{\mathrm{Sw}}-0.27 \%\right.\right.$ o $\left.]\right)$, error $\pm 0.7^{\circ} \mathrm{C}$, and corrected for the global ice volume component using the sea level curve of Miller et al. (2011). The Bemis et al. (1998) equation has been calibrated down to $15^{\circ} \mathrm{C}$, within a temperature range similar to that of the Messinian period. Moreover, the used equation has been considered as the most accurate paleotemperature equations for estimating SST (including the Late Miocene) for symbiotic foraminifera in (sub)tropical settings (Farmer et al., 


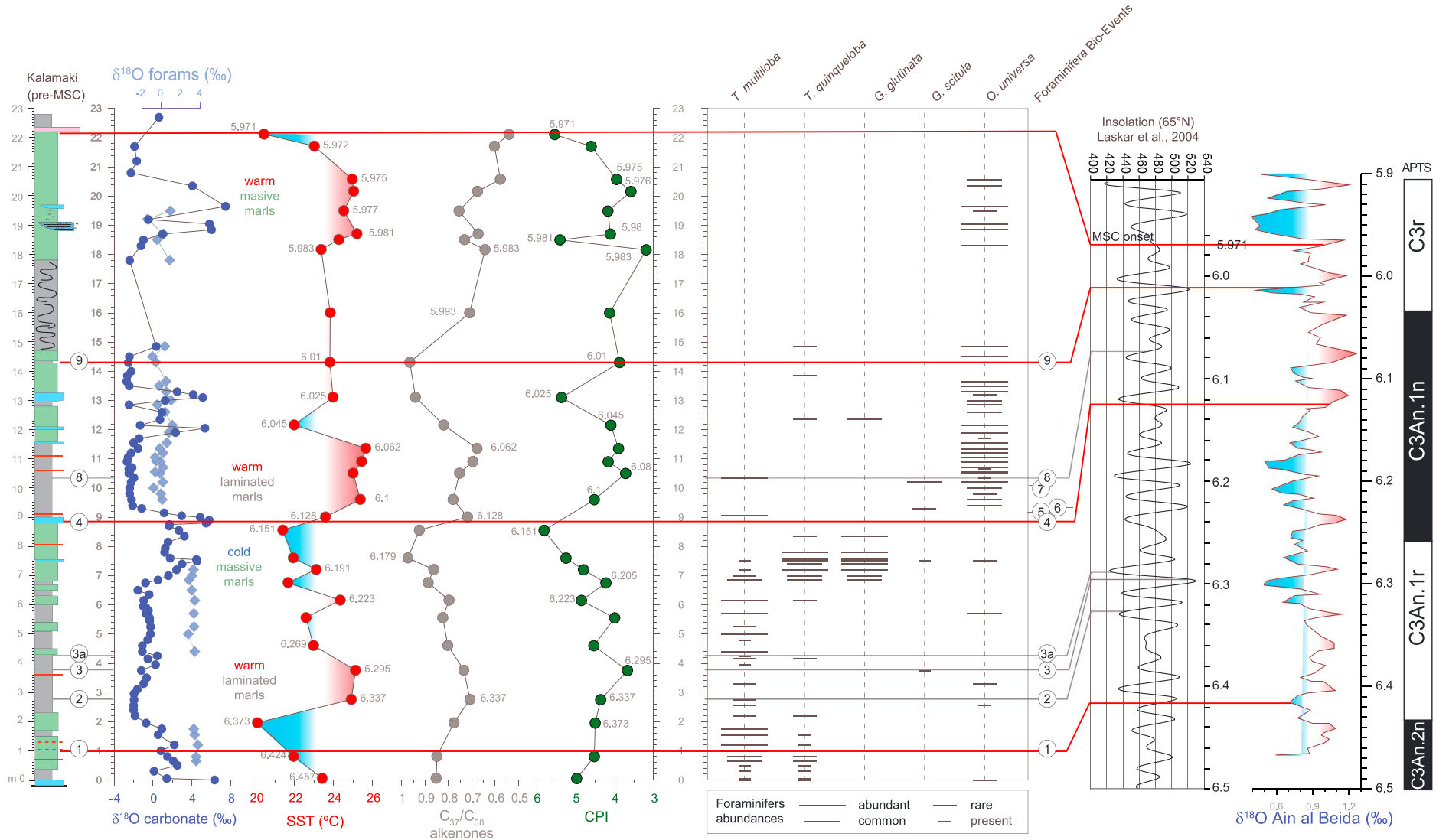

Figure 4. Sea surface temperature (SST) and alkenone data on Kalamaki section from the pre-Messinian Salinity Crisis (MSC) interval. The Mediterranean Sea SST was estimated using $U^{K}{ }_{37}$. The $\mathrm{C}_{37} / \mathrm{C}_{38}$ alkenones ratio, and carbon preference indices (CPIs) are presented. Remark the reverse scales for $\mathrm{C}_{37} / \mathrm{C}_{38}$ alkenones

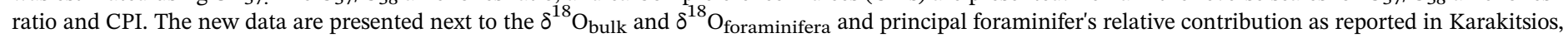
Roveri, et al. (2017). The numbers 1, 2, 3, 3a, 4, 5, 6, 7, 8, and 9 represent the foraminifera bioevents as in Karakitsios, Roveri, et al. (2017): (1) FAO Turborotalita multiloba; (2) FAO dextral Neogloboquadrina acostaensis; (3) Globorotalia scitula influx; (4) Neogloboquadrina acostaensis dominance sinistral; (5) Turborotalita multiloba influx; (6) G. scitula influx; (7) dominance N. acostaensis sinistral; (8) last abundant influx T. multiloba; (9) HO planktonic foraminifera. In the right-hand side is the astronomical insolation summer curve of Laskar et al. (2004), the $\delta^{18} \mathrm{O}$ of Ain al Beida reference section (Van der Laan et al., 2005), and the astronomically dated polarity time scale (Lourens et al., 2004). For clarity gray numbers next data point indicate ages in Ma.

2007; Williams et al., 2005). The sea level data were converted into mean ocean $\delta^{18} \mathrm{O}$ changes applying a $0.008 \%$ increase per meter of sea level lowering (Schrag et al., 2002) and were then subtracted from the $\delta^{18} \mathrm{O}_{\text {SW }}$ profile to obtain the regional ice volume-free $\delta^{18} \mathrm{O}_{\mathrm{SW}}\left(\delta^{18} \mathrm{O}_{\mathrm{IVF}} \mathrm{SW}\right)$, which were considered to approximate local variations in salinity. The full error propagation on calculated $\delta^{18} \mathrm{O}_{\mathrm{SW}}$ values suggested uncertainties of $\sim 0.31 \%$, in accordance with similar errors $\left( \pm 0.30 \%\right.$ ) reported for the $\delta^{18} \mathrm{O}_{\mathrm{Sw}}$ residuals during previous paleosalinity reconstructions (Antonarakou et al., 2015; Kallel et al., 1997; Rohling, 2007; Schmidt, 1999; Schmidt \& Lynch-Stieglitz, 2011). Absolute errors in $\delta^{18} \mathrm{O}_{\text {IVF-Sw }}$ were considered insignificant for the late Miocene, since changes in global ice volume were small (Williams et al., 2005). Lacking an estimate for the slope of the $\delta^{18} \mathrm{O}_{\mathrm{sw}}$-salinity relationship for the late Miocene, we used the modern $\delta^{18} \mathrm{O}_{\mathrm{sw}}$-salinity relationship (1\%o change in local salinity results in $0.41 \%$ change in local $\delta^{18} \mathrm{O}_{\mathrm{sw}}$ ) for the Mediterranean Sea (Kallel et al., 1997) to convert the $\delta^{18} \mathrm{O}$ anomaly to absolute SSS values.

There are two possible sources of error: (1) the seasonal effects on the isotopic and temperature signals due to growth and habitat differences between the foraminifera and the coccolithophores, respectively, and (2) the inherent error in assuming a constant $\delta^{18} \mathrm{O}_{\mathrm{sw}}$-salinity relationship and normalizing to modern conditions. Especially, in the late Miocene eastern Mediterranean setting with strong evaporation and/or freshwater inputs, a constant $\delta^{18} \mathrm{O}_{\mathrm{sw}}$-salinity relationship was possibly not true. In accordance with the observations of Rohling et al. (2004), we note that there is no correction for vital effect offsets in this study, because of (a) the absence of relevant values for specimens originating from the Mediterranean Sea and (b) the 


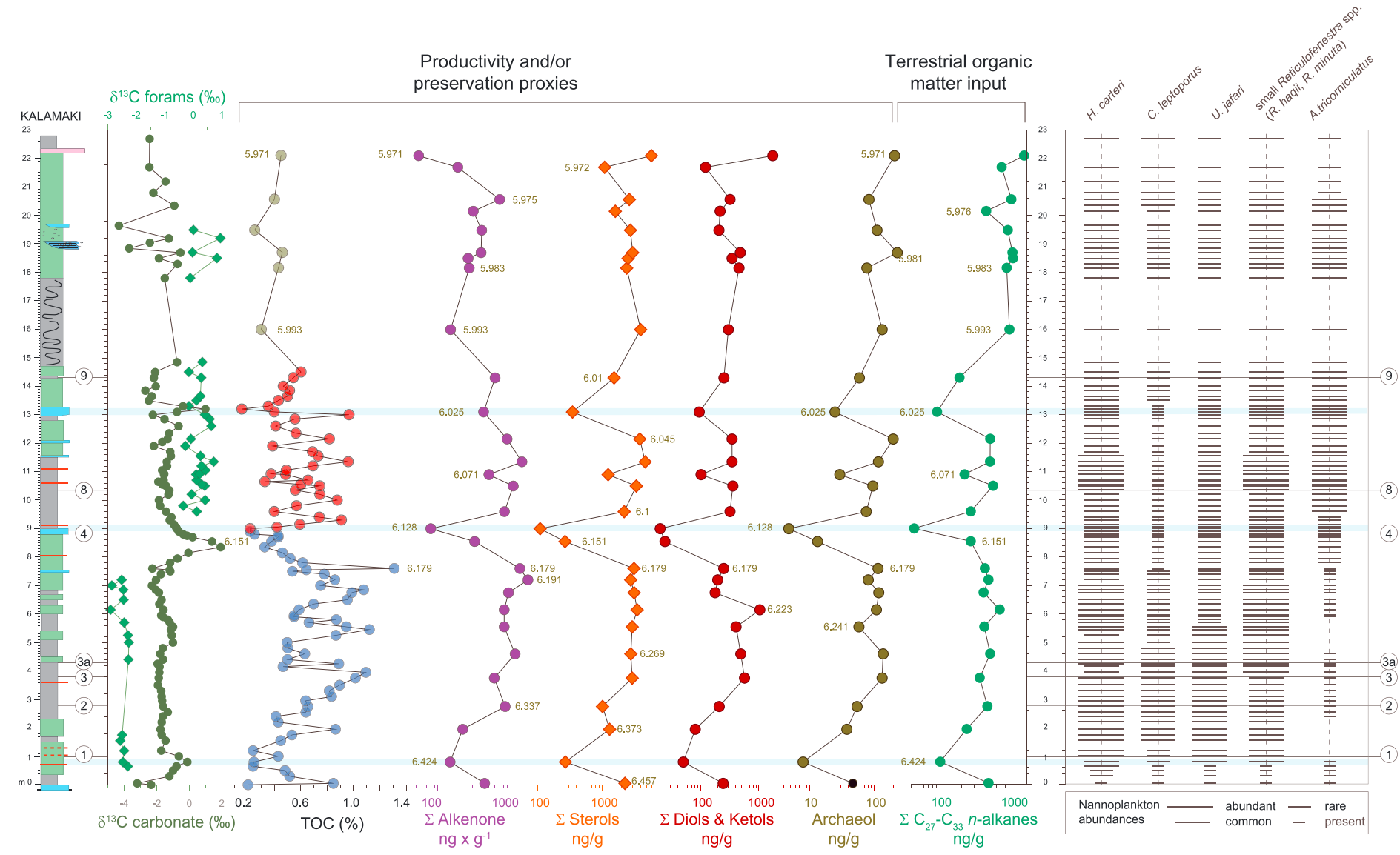

Figure 5. Biomarker data and total organic carbon (TOC) on Kalamaki section from the pre-Messinian Salinity Crisis interval. The new data are presented next to $\delta^{13} \mathrm{C}_{\text {bulk }}$ and $\delta^{13} \mathrm{C}_{\text {foraminifera }}$ and principal calcareous nannoplankton groups as in Karakitsios, Roveri, et al. (2017). TOCs in \% are plotted with different colors to mark the intervals with different sedimentation rates (see Figure 3). The values of the biomarkers are in ng/g and plotted on logarithmic scale. See also figure captions 4. Principal nannofossils relative contribution (Helicosphaera carteri, Calcidiscus leptoporus, Umbilicosphaera jafari, Reticulofenestra spp., and Amaurolithus tricorniculatus) as reported in Karakitsios, Roveri, et al. (2017) is plotted.

extensive genetic differentiation within planktonic foraminiferal morphospecies during the Neogene. Species-specific offsets are particularly difficult to estimate for species with broad vertical habitat ranges and/or species for which no culture data are available (Spero \& Lea, 1996). As a further illustration of this, for T. multiloba there is no oxygen isotopic disequilibrium values known, due to the fact that this species merely lived in a short time interval during the Late Miocene. Even for its modern ecological morphotype (T. quinqueloba) several works (Pados et al., 2015; Simstich et al., 2003; Volkmann \& Mensch, 2001) recorded a highly scattered and regionally distributed magnitude $(-1.1 \%$ in the Nordic Seas, $-1.3 \%$ in the Fraim Strait and Laptev Sea-northern Siberia, $-3.7 \%$ in the Arctic Ocean). We also highlight that all these values come from different settings beyond the study area and therefore are reported as extra-Mediterranean vital effects. Moreover, the calcification of O. universa, which includes a number of cryptic species (Morard et al., 2009), can occur under varying environmental and physiological conditions (e.g., symbiont photosynthetic rates) as a foraminifer matures and slowly floats across different depths in its photic zone habitat range (0-100 m; Farmer et al., 2007), resulting in variable (positive to negative; +0.33 to $-0.19 \%$; Bemis et al., 1998; Erez \& Luz, 1983; Ortiz et al., 1996) vital effects. In view of all these uncertainties, it is more sensible to work with actually measured values than values derived from a potentially erroneous correction and therefore refrain from doing such a correction.

\section{4. $\mathrm{C}_{37} / \mathrm{C}_{38}$ Alkenone Ratio}

Each sample contained long-chain $\mathrm{C}_{37}$ and $\mathrm{C}_{38}$ alkenones in variable amounts. To monitor the changes in the alkenone producers, the $\mathrm{C}_{37} / \mathrm{C}_{38}$ ratio was calculated as the ratio between the areas under the respective chromatogram peaks (Figure 5). 


\subsection{CPI and ACL}

The samples contained long-chain $\left(\mathrm{C}_{24}-\mathrm{C}_{35}\right) n$-alkanes with a distinct odd over even predominance in chain length. The degree of oddity (carbon preference index [CPI], Bray \& Evans, 1961, and average chain length [ACL], modified from Poynter \& Eglinton, 1990) are expressed as follows:

$$
\begin{aligned}
& C P I=0.5 \times\left(\frac{A 25+A 27+A 29+A 31+A 33}{A 24+A 26+A 28+A 30+A 32}+\frac{A 25+A 27+A 29+A 31+A 33}{A 26+A 28+A 30+A 32+A 34}\right), \\
& A C L=\frac{25 \times A 25+27 \times A 27+29 \times A 29+31 \times A 31+33 \times A 33}{A 25+A 27+A 29+A 31+A 33},
\end{aligned}
$$

where $A$ represents the area under the chromatogram peak for the respective individual $n$-alkane.

\subsection{Total Organic Carbon}

To determine the total organic carbon (TOC) content, 96 samples were analyzed at the Hydrocarbons Chemistry and Technology research unit of the Technical University of Crete. The samples were powdered and sieved through a 60 -mesh $(250 \mu \mathrm{m})$ sieve, and $100 \mathrm{mg}$ of each pulverized sample were heated in a helium atmosphere using an oven. A Rock-Eval II (Delsi Inc.) analyzer was used to measure the TOC content (wt\%) under standard conditions (Lafargue et al., 1998; Figure 5).

\section{Results}

\subsection{Pre-MSC SST}

$\mathrm{U}^{K^{\prime}}{ }_{37}$ varies between 0.71 and 0.89 , corresponding to an SST range between 20.1 and $25.7^{\circ} \mathrm{C}$ (mean $23.6^{\circ} \mathrm{C}$ ), indicating more than $5^{\circ} \mathrm{C}$ variation in the $22.23 \mathrm{~m}$ of section that covers $0.5 \mathrm{Myr}$ (6.42 to $5.971 \mathrm{Ma}$; Figure 4 and Table S1). Three warmer intervals, with SST values higher than $23.5^{\circ} \mathrm{C}$, are distinguished: (1) between 6.337 and 6.295 Ma (2.75-3.75 m), (2) between 6.1 and 6.062 Ma (9.6-11.33 m), and (3) between $\sim 6.01 \mathrm{Ma}$ and the MSC onset (18.7-20.57 m). Colder peaks, with SST values less than $23.5^{\circ} \mathrm{C}$, are also noticed. The lowest temperature $\left(20.1{ }^{\circ} \mathrm{C}\right)$ occurred at $6.373 \mathrm{Ma}(1.95 \mathrm{~m})$. Lower temperatures averaging around $22.6^{\circ} \mathrm{C}$ and with a minimum of $21.9^{\circ} \mathrm{C}$ are recorded between 6.269 and $6.151 \mathrm{Ma}$ (4.6 and $8.55 \mathrm{~m}$ ). This period is interrupted by a short warm event with $24.3^{\circ} \mathrm{C}$ recorded at $6.223 \mathrm{Ma}(6.15 \mathrm{~m})$. Colder peaks are also recorded at $6.045 \mathrm{Ma}(12.5 \mathrm{~m})$ with $22.5^{\circ} \mathrm{C}$ and at $5.971 \mathrm{Ma}(22.11 \mathrm{~m})$ with $21.2^{\circ} \mathrm{C}$. The temperature between $\sim 6.01$ and $5.983 \mathrm{Ma}(13.1$ and $18.16 \mathrm{~m})$, covering the slumping interval, records constant values of $23.8 \pm 0.2^{\circ} \mathrm{C}$.

\subsection{Pre-MSC SSS}

SSS ranges from $35.87 \%$ o to $47.90 \%$ (Figure 6) along the pre-evaporitic sequence of Kalamaki section. SSS exceeds $40 \%$ o between 6.457 and $6.151 \mathrm{Ma}(0-8.55 \mathrm{~m})$ reflecting a hypersaline water column. Following this salty interval, salinity decreases by $\sim 2 \%$ on average and fluctuates between minimum (35.9-38.3\%o) and maximum (39.5-41.2\%o) values. Around 5.977 Ma, we observe a sharp and abrupt SSS increase from $35.9 \%$ to $41.5 \%$.

\subsection{TOC}

The TOC content varies between $1.31 \%$ and $0.15 \%$ (average $=0.56 \%$; Figure 5 ). The largest TOC variation, $1.11 \%$, is recorded between 0 and $9 \mathrm{~m}$ (6.457-6.128 Ma; TOC values between $1.31 \%$ and $0.2 \%)$. The TOC is lower in the massive marls and carbonate-rich beds, and higher contents characterize in the laminated marls. In the upper part of the section, above the slump interval up to the MSC onset, TOC shows small variation (Figure 5).

\subsection{Biomarker as Tracers of Marine and Terrestrial Inputs of Organic Matter} 4.4.1. Biomarkers of Marine Origin

\subsubsection{Alkenones}

Six individual $\mathrm{C}_{37}$ and $\mathrm{C}_{38}$ alkenones were detected in all samples: heptatriacontatrien-2-one, heptatriacontadien-2-one, octatriacontadien-3-one, octatriacontadien-2-one, octatriacontatrien-3-one, and octatriacontatrien-2-one. Their total sum $\left(\mathrm{C}_{37}-\mathrm{C}_{38}\right.$ alkenone $)$ indicates that alkenone-producing algae were important producers for the autochthonous organic matter in the eastern Mediterranean surface waters before the MSC. In Kalamaki the concentrations vary from 54 to $1,703 \mathrm{ng} / \mathrm{g}$ (average = 611 ng/g; 


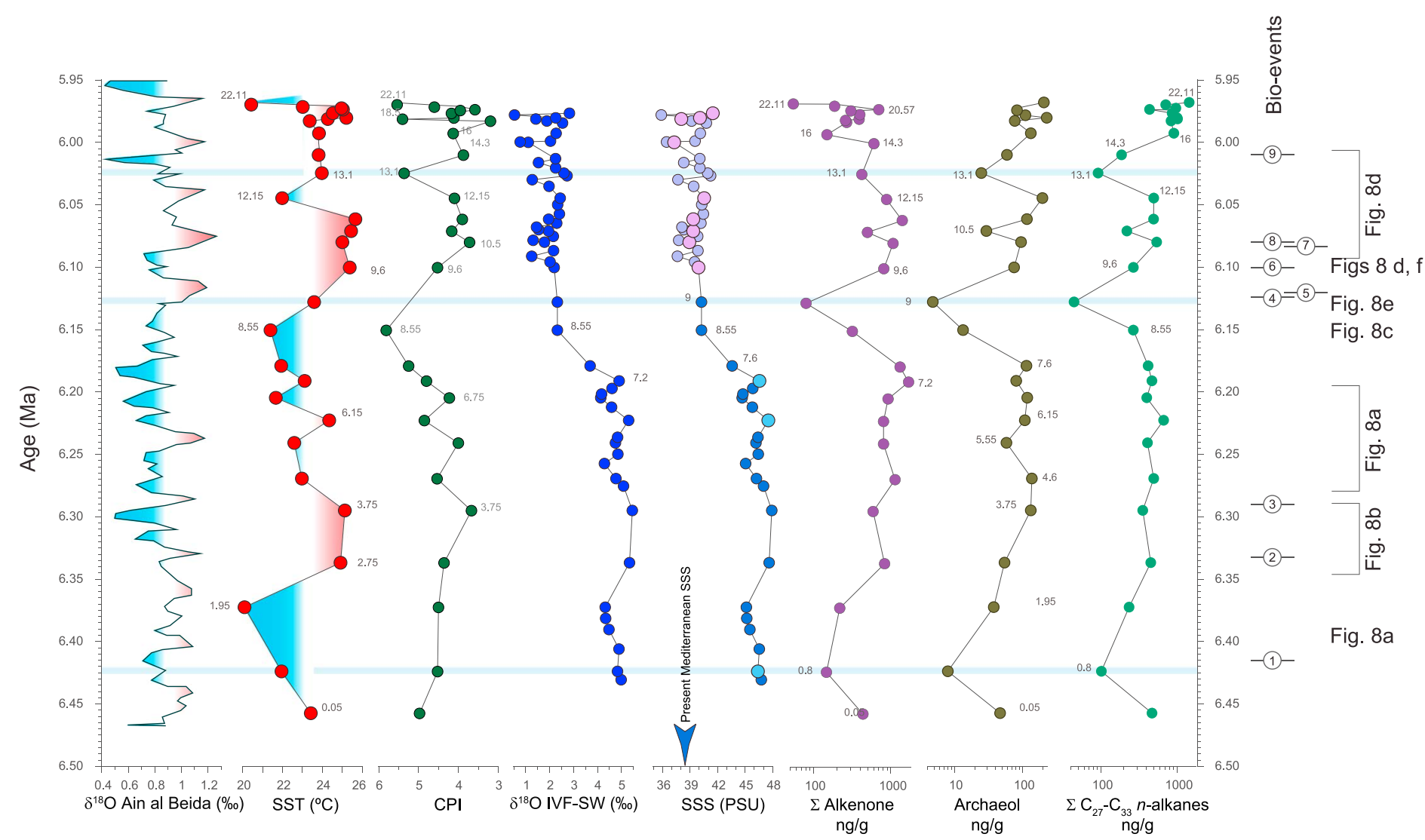

Figure 6. Compilation of representative data describing paleoenvironmental changes in the Mediterranean. In the salinity calculations plot the values older than $6.12 \mathrm{Ma}(9 \mathrm{~m})$ were using the $\delta^{18} \mathrm{O}$ measured on T. multiloba while those younger than $6.12 \mathrm{Ma}$ were using the $\delta^{18} \mathrm{O}$ measured on $O$. universa. Larger symbols, with slightly different colors represent the set points, levels where both SST based on $U^{k}{ }_{37}$ and $\delta^{18} \mathrm{O}$ were measured. The age model is based on Karakitsios, Roveri, et al. (2017). For clarity gray numbers next data point indicate stratigraphic level in meters. SST = sea surface temperature; SSS = sea surface salinity; $\mathrm{CPI}=$ carbon preference index.

Figures 4 and 5 and Table S1). Four levels show remarkably low values ( $<150 \mathrm{ng} / \mathrm{g}$ ) at 0.8, 9, 16, and $22.11 \mathrm{~m}$ (6.424, 6.128, 6.025, and 5.971 Ma, respectively). Low concentrations typify carbonate beds and massive marls. Conversely, higher contents were measured in laminated marls. Higher alkenone concentrations are found in the lower part of Kalamaki section (average $=811 \mathrm{ng} / \mathrm{g}$ ), with an increasing trend from $147 \mathrm{ng} / \mathrm{g}(0.8 \mathrm{~m})$ to $1,703 \mathrm{ng} / \mathrm{g}(7.2 \mathrm{~m})$. A sharp decrease follows down to a minimum of $80 \mathrm{ng} / \mathrm{g}(9 \mathrm{~m})$. An increasing trend up to $1,411 \mathrm{ng} / \mathrm{g}$ is observed until $11.35 \mathrm{~m}$, followed by a generally decreasing trend to $605 \mathrm{ng} / \mathrm{g}$ at $14.3 \mathrm{~m}$. The rest of the section shows low concentration of alkenones, averaging around $301 \mathrm{ng} / \mathrm{g}$.

The $\mathrm{C}_{37} / \mathrm{C}_{38}$ alkenone ratio varies between 0.54 and 0.97 (Table S1; Figure 4). The $\mathrm{C}_{37} / \mathrm{C}_{38}$ alkenone ratio (plotted in reverse order) closely mimics the SST trend up to $14.3 \mathrm{~m}$ (6.01 Ma). From $14.3 \mathrm{~m}$ to the last sample at $22.11 \mathrm{~m}$ (6.01 and 5.971 Ma), the $\mathrm{C}_{37} / \mathrm{C}_{38}$ ratio does not follow the SST trend but decreases instead, indicating increasing relative contribution of $\mathrm{C}_{38}$ alkenone. The laminated marls have lower ratios than the massive marls. Three intervals with lower $\mathrm{C}_{37} / \mathrm{C}_{38}$ alkenone ratios are distinguishable: between 2.75 and $3.75 \mathrm{~m}$ (6.337-6.295 Ma), between 9.6 and $11.33 \mathrm{~m}$ (6.128-6.062 Ma), and between 16 and $22.11 \mathrm{~m}$ (5.993-5.971 Ma).

\subsubsection{Sterols}

All samples exhibit a suite of $\mathrm{C}_{27}-\mathrm{C}_{30}$ compounds (Figure 5; Table S1). Cholesterol (cholest-5-en-3b-ol), the most abundant $\mathrm{C}_{27}$ sterol found, originates from a variety of planktonic organisms, mainly zooplankton (Volkman, 2003). Among $\mathrm{C}_{28}$-sterols, brassicasterol (24-methylcholest $\alpha$-5,22-dien-3 $\beta$-ol), a major sterol in various diatoms, found also in some haptophytes, largely predominates (Volkman et al., 1989). $\mathrm{C}_{29}$ sterols identified are sitosterol (24-ethylchol-est-5-en-3b-ol) and stigmasterol (24-ethylchol-est-5,22-dien-3b-ol). In oceanic settings, these are predominantly attributed to planktonic sources (Volkman, 2003). Dinosterol ( $4 \alpha, 23,24$-trimethyl-5 $\alpha$-cholest-22-en-3 $\beta$-ol), the $\mathrm{C}_{30}$-sterol detected in all samples, originates from 
dinoflagellates (Volkman, 2003). 5b(H)-saturated compounds (stanols) are found in lesser amounts than their unsaturated counterparts. In laminated marls, brassicasterol is consistently the most abundant single sterol, whereas in massive marls and carbonate beds, sitosterol predominates over brassicasterol along with cholesterol and dinosterol.

Total sterols concentrations range from 108 to 5,917 ng/g (average =2,423 ng/g, Figure 5). Massive marls (at 0.8 , 9, and $13 \mathrm{~m} ; 6.424,6.128$, and 6.025 Ma, respectively) are remarkably depleted in sterols $(<350 \mathrm{ng} / \mathrm{g})$. Laminated marls are significantly more enriched in sterols (average $>2,772 \mathrm{ng} / \mathrm{g}$ ). Three intervals with more sterols are identified: between 3.75 and $7.6 \mathrm{~m}$ (6.295-6.179 Ma), between 9.6 and $11.35 \mathrm{~m}(6.1-6.045 \mathrm{Ma})$, and between 16 and $21.7 \mathrm{~m}$ with constant elevated concentrations (5.993-5.971 Ma). The level at $22.11 \mathrm{~m}$ (5.971 Ma) is by far the most enriched in sterols (maximum $=5,917 \mathrm{ng} / \mathrm{g}$ ).

4.4.1.3. Diols and Ketols

The $\mathrm{C}_{30}$ alkandiol (mainly 1,15) is the major long-chain diol detected along with the corresponding longchain ketone. $\mathrm{C}_{28}$ and $\mathrm{C}_{33}$ diols at trace levels are not quantified. Sources of long-chain diols are eustigmatophytes (mainly the 1,13 and 1,15; Volkman et al., 1999), whereas 1,14 long-chain diols likely originate from Proboscia diatoms (Rampen et al., 2008). Long-chain keto-ols may be postdepositional oxidation products of the corresponding diols (de Leeuw et al., 1981).

The sum of diols and ketols varies over from 20 to $1,738 \mathrm{ng} / \mathrm{g}$ at $22.11 \mathrm{~m}$. Massive marls (0.8, 9, and $13 \mathrm{~m})$ are relatively depleted in diols and ketols $(<95 \mathrm{ng} / \mathrm{g})$. Laminated marls are more enriched in diols and ketols (average $>350 \mathrm{ng} / \mathrm{g}$ ). Thus, diols and ketols show the same trends as sterols. The sum of diols and ketols displays two evident peaks: at $6.15 \mathrm{~m}(6.223 \mathrm{Ma})$, and at $22.11 \mathrm{~m}$, close to the MSC onset (5.971 Ma).

4.4.1.4. Archaeol

Archaeol (2,3-di-O-phytanyl-sn-glycerol) is found at significant concentrations in all samples, indicating archaeal contribution to the marine biomass production (e.g., Schouten et al., 2013). It is a typical component in hypersaline settings ( $\mathrm{Li}$ et al., 2016), deriving most likely from halophilic Euryarchaeota (e.g., Lincoln et al., 2014). The extended archaeol $\left(\mathrm{C}_{20,25} s n-2, \mathrm{C}-7\right.$ hydroxy isoprenoid glycerol diether) is present at trace levels and not quantified.

Archaeol concentrations vary between $5 \mathrm{ng} / \mathrm{g}$ at $9 \mathrm{~m}$ (6.128 Ma) and $227 \mathrm{ng} / \mathrm{g}$ at $18.7 \mathrm{~m}$ (5.981 Ma). Similar to sterols, diols, and ketols, massive marls (at 0.8, 9, and $13.1 \mathrm{~m} ; 6.424,6.128$, and $6.025 \mathrm{Ma}$, respectively) are remarkably depleted in archaeol $(<25 \mathrm{ng} / \mathrm{g})$. Laminated marls are enriched in archaeol (average $>85 \mathrm{ng} / \mathrm{g}$ ): between 3.75 and $7.6 \mathrm{~m}$ (6.295-6.179 Ma), between 9.6 and $11.35 \mathrm{~m}$ (6.1-6.045 Ma), and between 16 and $21.7 \mathrm{~m}$ (5.993-5.972 Ma). The last interval is also dominated by two high peaks (archaeol $>200 \mathrm{ng} / \mathrm{g}$ ), at $18.7 \mathrm{~m}$ (5.981 Ma) and $22.11 \mathrm{~m}$ (5.971 Ma).

4.4.2. Biomarkers From Terrestrial Organic Matter

All samples contain $\mathrm{C}_{18}-\mathrm{C}_{33} n$-alkanes. Most abundant homologues spread within the $\mathrm{C}_{27}-\mathrm{C}_{33}$ range and show a strong odd-over-even carbon number predominance (CPI 3.2-5.8), maximizing at $n$-hentriacontane $\left(\mathrm{C}_{31}\right)$ and ACL minimally varying between 29.6 and 29.9. This compositional pattern is typical of higher plant waxes (Eglinton \& Hamilton, 1967). Consequently, we use the sum of the major plant wax components $\left(\mathrm{C}_{27}-\mathrm{C}_{33} n\right.$-alkanes) to track continentally derived material (freshwater input and runoff).

The $\mathrm{C}_{27}-\mathrm{C}_{33} n$-alkanes concentrations vary from 44.2 to $1,456 \mathrm{ng} / \mathrm{g}$ (Figure 5). There are two intervals with clearly different concentration ranges. Between 0 and $14.3 \mathrm{~m}$ (6.457-6.01 Ma), the $\mathrm{C}_{27}-\mathrm{C}_{33} n$-alkanes concentrations vary around an average of $355 \mathrm{ng} / \mathrm{g}$, whereas between 16 and $22.11 \mathrm{~m}$, they vary around an average of $915 \mathrm{ng} / \mathrm{g}$.

\section{Discussions}

\subsection{SST Variation Preceding the MSC in Kalamaki: Comparison to Other Records}

Absolute SST (20.1-25.7 ${ }^{\circ} \mathrm{C}$; Figures 6 and 7) between 6.457 and 5.971 Ma was higher than annual mean present-day SST $\left(19^{\circ} \mathrm{C}\right)$ in the study area (Figure 1; Table S2). The $5.6^{\circ} \mathrm{C}$ amplitude of SST change between warmer and colder periods between 6.457 and 5.971 Ma is somewhat smaller than the $8-9{ }^{\circ} \mathrm{C}$ Holocene glacial-interglacial variation in the Mediterranean Sea (Emeis et al., 2000). No alkenone-based SSTs are available for the interval just preceding the MSC onset. Consequently, no direct comparison is possible. A long-term, alkenone-based SST record is available for the interval 12.9-6.3 Ma (Tzanova et al., 2015) from 


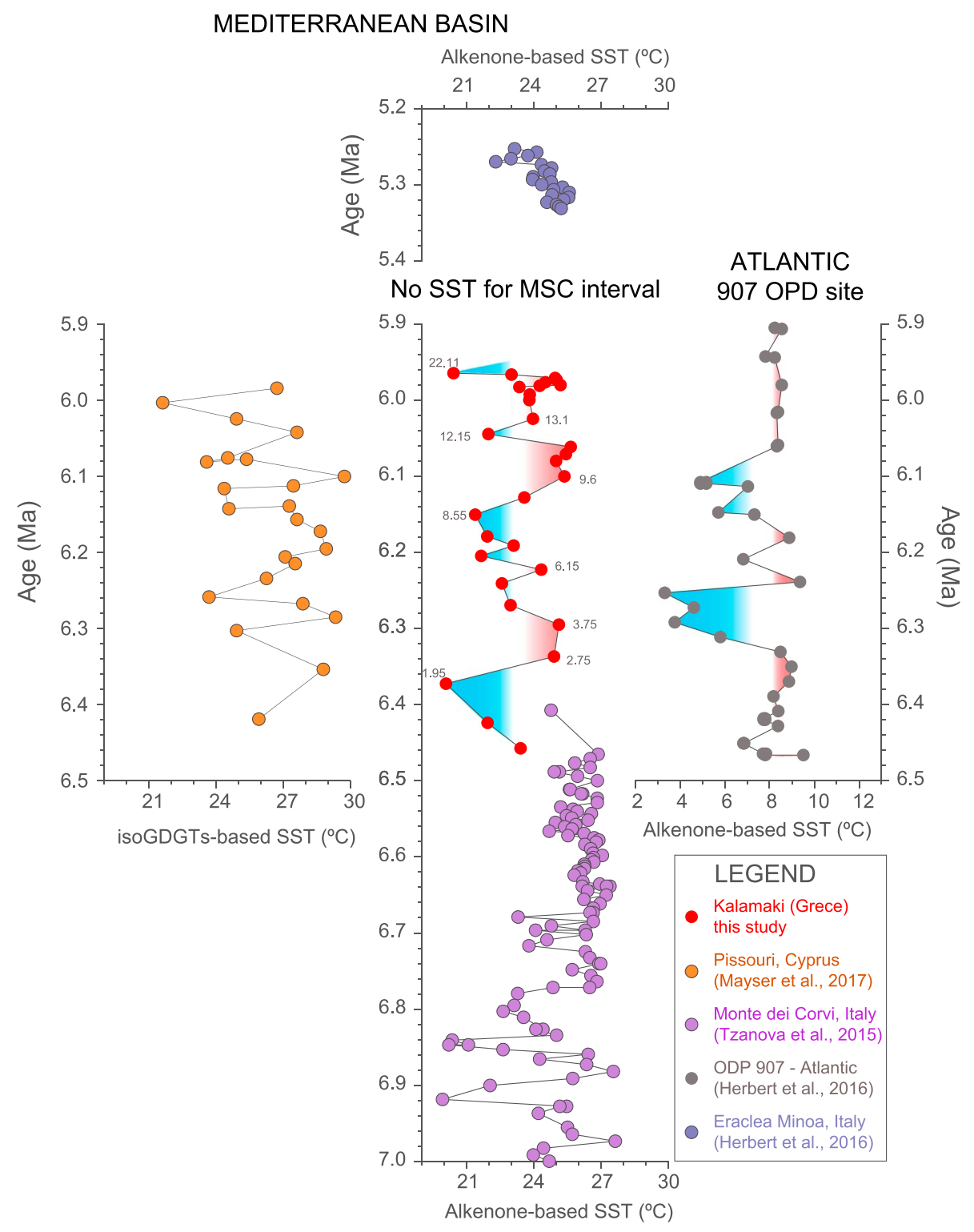

Figure 7. Alkenone-based SST record from Mediterranean Sea during late Miocene to Pliocene transition. Kalamaki and records of Herbert et al. (2016) and Tzanova et al. (2015) are the only published alkenone SSTs. SST = sea surface temperature; MSC = Messinian Salinity Crisis.

Monte dei Corvi ( $4^{\circ}$ more to the north than Kalamaki section; Figure 1). The Monte dei Corvi record shows a much warmer than today Tortonian climate (SST $=27-28^{\circ} \mathrm{C}$ ), while the Messinian starts with significantly lower temperatures $\left(\sim 19^{\circ} \mathrm{C}\right.$; Tzanova et al., 2015). Close to our studied time interval, warm conditions were re-established $\left(\sim 26^{\circ} \mathrm{C}\right)$ at Monte dei Corvi location. Meanwhile in Kalamaki the maximum estimated SST was $\sim 2{ }^{\circ} \mathrm{C}$ lower than the maximum from the Tzanova et al. (2015) record. The minimum value $\left(20.1{ }^{\circ} \mathrm{C}\right)$ and the SST variability in Kalamaki are close to the Early Messinian of the Monte dei Corvi $\left(19.5^{\circ} \mathrm{C}\right)$. Yet SST variability is greater in the Late Messinian Kalamaki than in the Middle Messinian Mediterranean alkenone-based SST record (Tzanova et al., 2015). For the Kalamaki time equivalent (6.457-5.971 Ma), SST estimates are available from Atlantic ODP sites 907 and 982. Both records indicate large SST variations between 7.5 and 5.5 Ma, during the so-called Late Miocene cooling (Herbert et al., 2016). Especially, in the $907 \mathrm{ODP}$ site, one cooling of $6{ }^{\circ} \mathrm{C}$ is recorded at $6.3-6.25 \mathrm{Ma}$ and one $4{ }^{\circ} \mathrm{C}$ cold episode at 6.11 Ma (Figure 7). We can argue that the large SST amplitudes we observe in our record are recording 
the same type of temperature variation. Comparing Zanclean SST data from Kalamaki $\left(28-30{ }^{\circ} \mathrm{C}\right.$; Kontakiotis, Karakitsios, et al., 2016) and Eraclea Minoa (Italy; Herbert et al., 2016) sections, we observe that the highs in our record are consistent with the relatively stable SSTs $\left(24-26^{\circ} \mathrm{C}\right)$ between 5.33 and $5.25 \mathrm{Ma}$; therefore, the Mediterranean Sea was equally warm before and after the MSC. During the latest Zanclean ( 4.1-3.25 Ma), the eastern Mediterranean was similarly warm $\left(\sim 26{ }^{\circ} \mathrm{C}\right.$; Athanasiou et al., 2017$)$.

Mayser et al. (2017) produced the only known proxy Mediterranean Sea SST record for the equivalent time interval (6.457-5.971 Ma; Pissouri section, Cyprus; Figures 1 and 7). However, Mayser et al. (2017) used $\mathrm{TEX}_{86}$, which is based on glycerol dialkyl glycerol tetraethers produced by Taumarchaeota. Mayser et al. (2017) indicated SSTs between $\sim 22$ and $\sim 30^{\circ} \mathrm{C}\left( \pm 2-3{ }^{\circ} \mathrm{C}\right)$, slightly higher than the $\mathrm{U}^{K^{\prime}}{ }_{37}$ SST estimates of $\sim 20.1$ to $\sim 25.7^{\circ} \mathrm{C}$ for Kalamaki. This difference can be partly attributed to the usage of different methods based on different biomarkers produced by different groups of organisms. The $>3^{\circ}$ latitudinal difference between the locations of the two sections (Kalamaki in Greece and Pissouri in Cyprus) should be the most likely cause of the observed SST variance.

\subsection{Alkenone-Based SSTs Versus Planktonic Foraminifera and Nannofossils Inferences}

Based on alkenone SST estimates, two distinct intervals can be distinguished: (1) mostly colder, on average $22.9{ }^{\circ} \mathrm{C}$, between 0 and $9 \mathrm{~m}(6.457$ to $6.128 \mathrm{Ma})$ and (2) mostly warmer, on average $24.1^{\circ} \mathrm{C}$, between 9 and $22.11 \mathrm{~m}$ (6.128 and 5.971 Ma; Figures 4 and 6).

The trends observed in the alkenones-based SSTs from Kalamaki are supported by the faunal planktonic abundances (Figure 4). The presence of T. quinqueloba, Neogloboquadrina acostaensis, T. multiloba, and G. glutinata indicates colder condition for the interval between 0 and $7 \mathrm{~m}$ ( 6.457 to $6.205 \mathrm{Ma}$ ), with the exception of the 2.8- to 4.2-m part (6.337 to $6.295 \mathrm{Ma}$ ) when SSTs indicate warming. The generally colder phase between 6.45 and $6.128 \mathrm{Ma}$ is well correlated to the colder period inferred from $\delta^{18} \mathrm{O}$ data from Atlantic, Ain al Beida section (Van der Laan et al., 2005; Figures 4 and 6).

The SST decreasing trend ends at $\sim 8.55 \mathrm{~m}(6.151 \mathrm{Ma})$. Afterwards, at $\sim 9 \mathrm{~m}(6.128 \mathrm{Ma})$, a warm interval starts prevailing until the top, at $22.11 \mathrm{~m}(5.971 \mathrm{Ma})$. These trends are evident in all alkenone-based SST, foraminifera, and nannofossils records. The fauna is composed of warm water species such as $O$. universa and $G$. obliquus. Within this interval, at about $12.15 \mathrm{~m}(6.045 \mathrm{Ma})$, a brief rebound to colder conditions (SST of $22{ }^{\circ} \mathrm{C}$ ) is observed, supported by the slight decrease of warm water species and the increase of G. glutinata. The cooling phase is punctuated by higher salinity conditions (supported by remarkable similarity between the $\delta^{18} \mathrm{O}$ carbonate and the $\delta^{18} \mathrm{O} O$. universa). Finally, the interval overlying the slump seems to be a warm interval characterized by high $O$. universa blooms with high SSTs (average of $24{ }^{\circ} \mathrm{C}$ ). The presence of Amaurolithus sp. between 9 and $22.11 \mathrm{~m}$ supports the prevalence of warm water conditions between 6.121 and $5.96 \mathrm{Ma}$. This warmer phase is well correlated to the warm period inferred from $\delta^{18} \mathrm{O}$ data from Ain al Beida record (Van der Laan et al., 2005; Figures 4 and 6).

\subsection{SST Expressed in Lithology in Kalamaki}

The laminated marls from Kalamaki section were deposited during SST maxima that provoked warming followed by increased river runoff (Figures 8b, 8d, and 8f). The highest SSTs are recorded during the laminated marls marked intervals. The warmer intervals with increased fresh water river runoff were accompanied by enhanced nutrient supply consequently generating higher productivity in the surface waters leading to intermittent oxygen depletion. The situation is similar to the sapropel formation during the Pliocene-Pleistocene (Athanasiou et al., 2017). Similarly, the sapropels before 6.45 Ma (Tzanova et al., 2015) formed immediately after cold climatic episodes. The massive marls and two calcareous marls (at 9 and $13 \mathrm{~m}, 6.128$ and 6.025 Ma, respectively) are associated with colder periods (Figures 4, 8a, and 8c) with the exception of the part of the section above the slump, where relatively warmer conditions typified the interval marked by increased accumulation rate (Figures 3 and 4).

High SSTs are associated with low $\delta^{18} \mathrm{O}$ measured on bulk sedimentary rocks (Figure 4). We therefore infer that at the site location, the Mediterranean Sea was saltier during colder intervals, expressed by increasing $\delta^{18} \mathrm{O}$. This situation was governed by reduced riverine input generating a relatively more dominant influence of the marine component in the water balance of the Mediterranean Sea. 


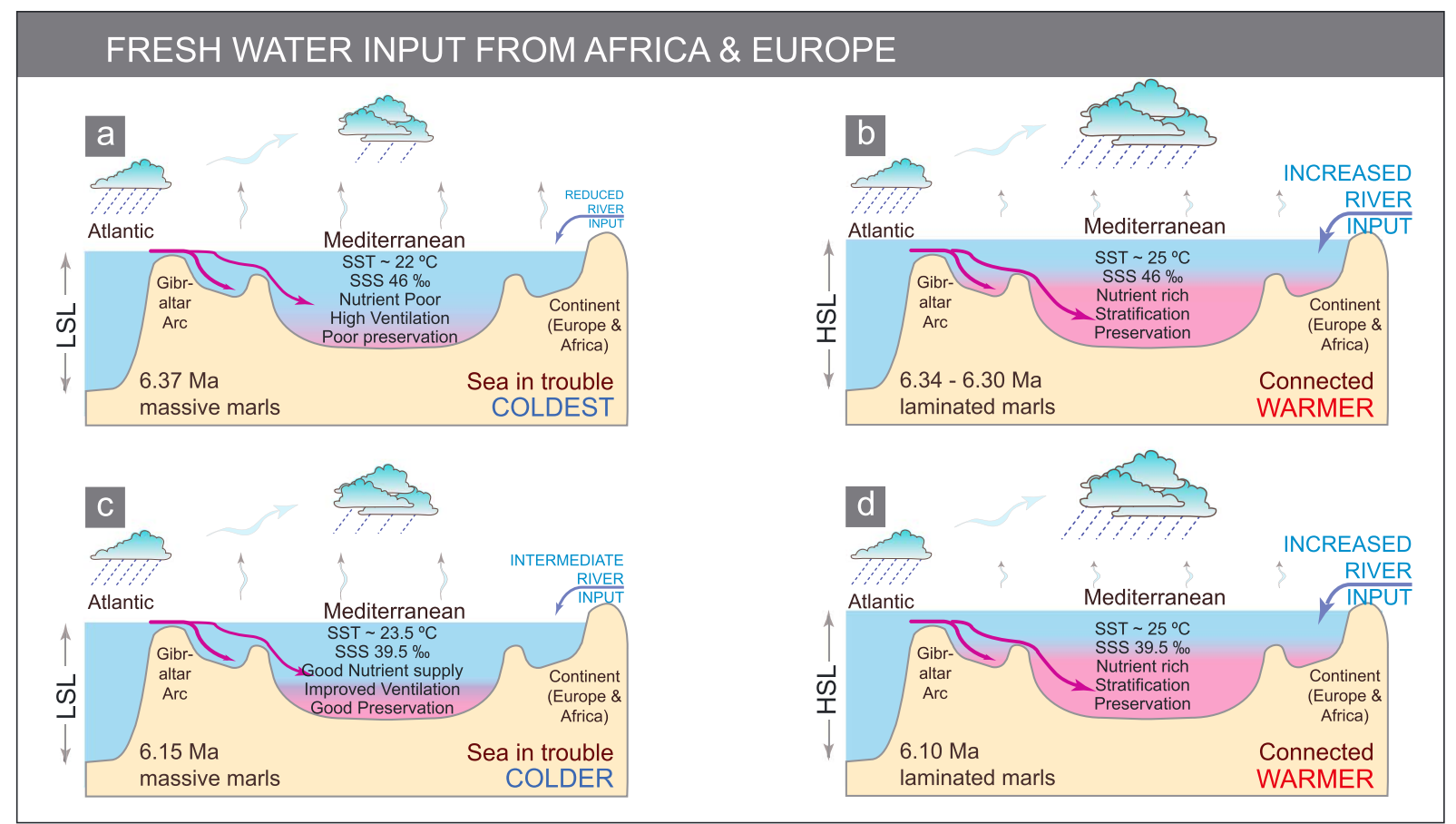

\section{FRESH WATER INPUT FROM AFRICA \& EUROPE AND PARATETHYS}

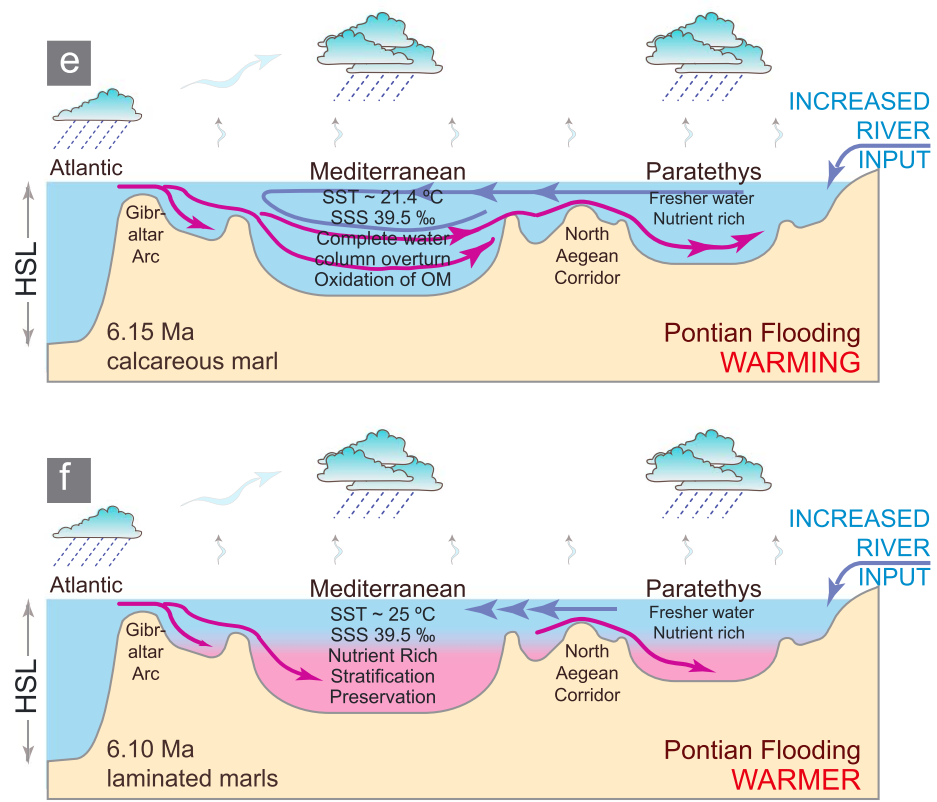

Arguments for

Paratethys-Mediterranean exchange

1) In Paratethys are present marine planktonic \& benthic foraminifera and calcareous nannofossil assemblages that are correlative to Subzone NN11b.

2) The Pontian transgression is followed by the migration of faunal elements from the Pannonian Basin and the Aegean region into the Black Sea domain (Popov et al., 2006; Grothe et al., 2018).

Figure 8. Schematic representation of the environmental conditions during important changes in the pre-MSC Mediterranean Sea. (a) Coldest times under hyper saline conditions during deposition of massive marls. (b) Warmer phases, under hyper saline during deposition of laminated marls. (c) Colder times but under normal salinity conditions during deposition of massive marls. (d) During warmer phases, but under normal salinity conditions during deposition of laminated marls. (e) At 6.12 Ma, exchange with Paratethys (Grothe et al., 2018; Popov et al., 2006) led to increased fresher water supply, adding to the much increased freshwater from the rest of the continental realm. The Paratethys water could have form a fresher water layer on top of the Mediterranean water column. The salinity and possibly temperature contrast led to the total overturn in the water column, oxidation of the organic matter, moment marked by the presence of calcareous marl. (f) At 6.10 Ma, after the first Mediterranean-Paratethys water interaction, high density contrast between Paratethys waters and Mediterranean led to increased stratification of the water column. SST = sea surface temperature; SSS = sea surface salinity; Messinian Salinity Crisis. 


\subsection{Combining SST Changes With $\delta^{18} \mathrm{O}_{\mathrm{SW}}$ and Resulting Salinity Perturbations}

The long-term variability in SSS estimates of $35.87 \%$ o to $47.90 \%$ o exceeds by far the standard error of the measurements (Figure 6; Table S2); therefore, it has to be considered as meaningful. The SSS estimates are in the expected range of the box model Mediterranean SSS estimates (Simon et al., 2017) during the pre-evaporitic Messinian stage. Between 6.457 and 6.128 Ma the Mediterranean Sea was hypersaline, with SSSs exceeding 40\%o (Figures 8a and 8b). The hypersaline phase appeared simultaneously with times where SSTs indicated colder conditions, in line with reported saltier Mediterranean Sea during cold periods (van der Meer et al., 2007). The only exception refers to the 6.35- to 6.30-Ma time interval, where both SST and salinity simultaneously increased. This interval is characterized by the presence of small-sized O. universa specimens. Given that no evidence (due to the absence of shell thickness- and pore size-related data) exists for discrete cryptic species on the basis of size variability in the Kalamaki section, we suggest the observed test size variability to document variable degrees of stunted growth. Therefore, we suggest that this level evidenced by small $O$. universa may represent the expression of stunted growth in response to suboptimal growth or stressed conditions (increased SST and salinity). Relevant episodes with particularly small O. universa and low planktonic foraminiferal abundances have been correlated with annual SSTs $>22^{\circ} \mathrm{C}$ and high water densities (28.5 g/L) (e.g., a salinity of $40.5 \%$ at $22^{\circ} \mathrm{C}$ ) in Late Miocene (Crete Island; Brachert et al., 2015) and Late Quaternary (Indian Ocean and Red Sea; Bé \& Duplessy, 1976; Haenel, 1987) sedimentary environments. The same phenomenon also appears in Globigerinita glutinata, where small size representatives of this species within the Mediterranean (Sorbas basin and Gavdos Island) have been suggested to mark short high salinity events. This interpretation is also consistent with recent findings from the eastern Mediterranean Sea (Antonarakou, Kontakiotis, Zarkogiannis, et al., 2018), where a close correspondence of planktonic foraminiferal abnormal (stunted growth indicators) specimens (including O. universa) in high salinity stress conditions is documented. After $6.151 \mathrm{Ma}$ a freshening trend of $\sim 2 \%$ is observed concomitant with warming in the Mediterranean Sea. The obtained SSS values for younger than 6.151 Ma are higher than 35.9-41.2\%o but close to the prescribed Atlantic salinity of $36.5 \%$. We suggest that the transition from the pre-evaporitic to the MSC was not characterized by a constant or gradual SSS increase; instead, it was punctuated by extreme or less SSS events, in accordance with modeled SSS variations (Ivanovic et al., 2014). At the top ( $\sim 5.971 \mathrm{Ma})$ the sharp and abrupt SSS increase from $35.9 \%$ to $41.5 \%$ o must be related to the inception of MSC (Manzi et al., 2013; Roveri et al., 2014).

During the prerestriction phase, the traditional method of calculating $\delta^{18} \mathrm{O}_{\text {IVF-Sw }}$ suggests significant SSS variation across the latest Messinian (Figures 6 and 7). The implied SSSs are indicative of normal to hypersaline marine conditions, highlighting the marine nature of the Mediterranean basin (Figures 7 and 8; Gennari et al., 2018). From 6.457 to $6.128 \mathrm{Ma}$, the SSSs obtained by both the $\delta^{18} \mathrm{O}_{\mathrm{IVF}-\mathrm{SW}}$ and SSS records indicate increasingly hypersaline conditions in the surface water column (Figures $8 \mathrm{a}$ and $8 \mathrm{~b}$ ). Surprisingly, the current constraints on extreme paleosalinity estimations are identical ( $\sim 6 \%$ o at $\sim 6.3 \mathrm{Ma}$ ) to previous SSS reconstruction within Mediterranean Sea (Monte dei Corvi; Tzanova, 2015). The hypersaline conditions are consistent with faunal (Blanc-Valleron et al., 2002; Drinia et al., 2007; Gennari et al., 2018; Kouwenhoven et al., 2003) and nannofossils evidence (Karakitsios, Cornée, et al., 2017; Karakitsios, Roveri, et al., 2017), suggesting that the latest Messinian Mediterranean experienced both surface and bottom water salinity much higher than today, further providing threshold values for reconstructing the Mediterranean's SSS history (e.g., $\sim 50 \%$ as the upper tolerance limit of foraminifera; Bijma et al., 1990). The absence of planktonic foraminifera in some intervals (Karakitsios, Cornée, et al., 2017; Karakitsios, Roveri, et al., 2017) or the monospecific presence of the high salinity (stressed) indicator of T. multiloba indicates that surface water salinity exceeded their $\sim 49 \%$ o tolerance (Fenton et al., 2000).

The SSS increase at this time interval may have resulted from the closure of Riffian Corridor at 6.646.44 Ma (Flecker et al., 2015) and part of the Betic counterparts (Krijgsman et al., 1999) provoking a sluggish communication with the open ocean. From 6.12 Ma to the MSC onset we observe a significant freshening of the Mediterranean water column with depleted $\delta^{18} \mathrm{O}_{\text {IVF-Sw }}$ values and SSS only slightly above modern values, determined by an increase of continental-derived waters (Gennari et al., 2018; Figure 8c). Fresher Paratethys water inflow could have been the alternative cause for freshening of the Mediterranean Sea, as, at $6.12 \mathrm{Ma}$, an influx of marine waters into Paratethys is documented (Krijgsman et al., 2010; Figure 8d). This event, known as the Pontian transgression, generated the installation of marine-like conditions into the neighboring Paratethys realm. The significantly fresher 
Paratethys waters could have provoked a salinity decrease in the (eastern) Mediterranean. This assumption is strengthened by the coincidental timing of these events: Freshening of the Mediterranean and Pontian Flood are at 6.10 and 6.12 Ma, respectively (Figures 8e and 8f). Modeling studies allow quantifying the salinity increase expected upon reduction in exchange with Atlantic; thus, the basin seems to increase its sensitivity to freshwater oscillations (Simon et al., 2017).

At 5.971 our approach points to a sudden increase in salinity (Table S2), which we interpret as the expression of the transitional interval (Manzi et al., 2013). This interval, identified between the Primary Lower Gypsum and the pre-evaporite phase, contains a discontinuous gypsum bed (Manzi et al., 2013). Although the evidence results from a single data point, the $35.9 \%$ to $41.5 \%$ o increasing SSS, possibly announces further restriction leading to the MSC stage 1 (Roveri et al., 2014; Figure 7). Although still speculative, if the trend would further be extrapolated to the MSC, the salinities could have reached $\sim 60 \%$ at $5.9 \mathrm{Ma}$, in agreement with modeling results (Ivanovic et al., 2014; Simon et al., 2017; Simon \& Meijer, 2017). Overall, the 6.2- to 5.9-Ma time interval, which represents the transition to evaporitic conditions at the top of the studied interval, corresponds to a semienclosed hydrological setting controlled by fluctuating freshwater diluted to hypersaline conditions resulting in significant salinity variations. The same evolutionary trend indicative of the transitional character of the environment has been described in other sections located in more (i.e., Serra Pirciata, Torrente Vaccarizzo, and Marianopoli; Bellanca et al., 2001) or less (Falconara/sGibliscemi composite section; Blanc-Valleron et al., 2002) marginal settings within the Mediterranean Sea. This indicates a severe isolation of the basin, the hydrological budget of which was longer regulated by the dominant control of climatic fluctuations rather than marine (Atlantic) inputs. The enhanced climate influence on depositional conditions induced strong changes in the surface water salinity, especially during time intervals of increased continental inputs which resulted in a dilution of the surface waters and the subsequent stratification of the water column.

\section{5. $\mathrm{C}_{37} / \mathrm{C}_{38}$ Alkenone Rations and SSTs Variation}

The $\mathrm{C}_{37} / \mathrm{C}_{38}$ ratios, displayed along an inverted axis, closely mimic the trend observed in the calculated SST up to $13.1 \mathrm{~m}$ (6.025 Ma; Figure 4). The inverse covariance suggests that changes in the alkenone producers were (in)directly determined by variation in SSTs. Lower $\mathrm{C}_{37} / \mathrm{C}_{38}$ ratios $(0.8-0.65)$ are found in laminated marls where SSTs are higher than $23.5{ }^{\circ} \mathrm{C}(2.75$ to $3.75 \mathrm{~m}, 6.337-6.295 \mathrm{Ma}$; 9.6 to $12.15 \mathrm{~m}$, 6.1-6.062 Ma; Figure 4). We therefore infer that changes in the alkenone producers were determined by increased freshwater influx during warmer periods. Higher $\mathrm{C}_{37} / \mathrm{C}_{38}$ ratios $(0.8-1)$ are found especially during the colder interval (4.6 to $8.55 \mathrm{~m}$; 6.269-6.151 Ma). Equivalent $\mathrm{C}_{37} / \mathrm{C}_{38}$ values, overlapping with gradual SST decrease, were documented between 4.2 and 3.0 Ma in the Gulf of Cadiz (Furota et al., 2016). The increase of $\mathrm{C}_{37} / \mathrm{C}_{38}$ ratios was attributed to changes in the assemblage of alkenone producers: from only genus Reticulofenestra to Gephyrocapsa and Reticulofenestra genera (Furota et al., 2016). In Kalamaki section no small Gephyrocapsa were identified. However, the 0.8 to $0.97 \mathrm{C}_{37} / \mathrm{C}_{38}$ values during cold times in Kalamaki section suggest a causal relationship to upwelling conditions inferred from the small O. universa occurrence. Previous studies have shown also that $\mathrm{C}_{37} / \mathrm{C}_{38}$ ratios vary for the same species according to the growth status and/or under nutrient depletion (e.g., Conte et al., 1998; Prahl et al., 2003). In addition, $\mathrm{C}_{37} / \mathrm{C}_{3} 8$ ratios can present large variabilities within the same species (0.5 to 2.6 for $E$. huxleyi; 5.5 to 15 for I. galbana; Chu et al., 2005). Noticeably, the interval with $\mathrm{C}_{37} / \mathrm{C}_{38}$ ratios between 0.65 and 0.54 is exclusively attributed to the uppermost part of the section (16 to $22.11 \mathrm{~m}$, between 5.993 and $5.971 \mathrm{Ma}$ ) announcing important changes in the alkenone producers determined by increasingly stressed environmental conditions (i.e., stronger stratification in the water column) that led to the onset of the MSC.

\subsection{Productivity, Terrestrial Input, and Preservation Influence on TOC Variations} 5.6.1. TOC and Biomarkers Variation Kalamaki Section

The TOC values are similar (Table S3), in range (0.15-1.31\%) and amplitude variation, to the TOC of sediments of the past 16 kyrs from the Ionian Sea (Emeis et al., 2000). Although the pre-MSC Kalamaki section covers a different timescale than the Holocene record, we can safely argue that changes, similar to those during sapropel formation, were taking place during the formation of laminated 
marls in Kalamaki pre-MSC section. TOC enhancements coincide with lamination, as prime evidence for bottom water oxygen depletion.

In any aquatic system the organic carbon accumulation depends on the combined effect of (1) primary productivity, (2) preservation, and (3) input of terrestrial organic matter. In Kalamaki, the variation in marine primary productivity is reflected in the total sum of the alkenones; sterols; diols; ketols; and, to a certain extent, archaeol. Total alkenone data indicate that our values are once again similar to the alkenones records from the recent Holocene of Ionian Sea, where the transition to and into sapropel sums alkenones in the range of $1,300 \mathrm{ng} / \mathrm{g}$; the layers below and above sapropel having much lower alkenones amounts (Emeis et al., 2000). The sterols, biomarkers used as productivity proxy, follow closely the alkenones' trend with the exception of the last sample, at $22.11 \mathrm{~m}$ (5.971 Ma; Figure 5). Equally, the archaeol, biomarker for certain metanotrophic and methanogenic Archaea (e.g. Birgel et al., 2008), mimics the alkenone trend with the exception of the last sample at $22.11 \mathrm{~m}$ (5.971 Ma). The general covariance of alkenones and sterols could indicate enhanced productivity in the euphotic zone. The covariance of archaeol versus alkenones and sterols could indicate that productivity was also determined by methanotrophic and methanogenic archaea. However, the archaeol increase hints toward enhanced stratification toward the onset of the MSC in the top of Kalamaki section. Our SSS estimates indicate that surface water salinity was typical of normal marine. However, what happened in the deeper of the late Messinian Mediterranean water column is not known since normal-marine conditions could have been the lid on top of denser (saltier and/or colder) deeper water. On similar line of reasoning, based on changes in the archaeal community at the transition into MSC in Piedmond basin (Italy), Natalicchio et al. (2017) suggest occurrence of stratification and hypoxia like in the modern stratified Black Sea basin. The sum of $\mathrm{C}_{27}$ to $\mathrm{C}_{33} n$-alkanes, biomarkers for vascular higher plants that indicate the terrestrial organic matter input into the Mediterranean, covaries too with all presented biomarkers. The covariance of all biomarkers (including the sum of $\mathrm{C}_{27}$ to $\mathrm{C}_{33} n$-alkanes) could in fact represent a preservation signal since the long-chain $n$-alkanes are mostly terrestrial in origin. Noticeably, at $0.8,9$, and $13.10 \mathrm{~m}$ in the section (6.424, 6.128, and 6.025 Ma, respectively), the effect of oxygenation in the bottom waters (at SST lows and SSS highs) reduced the preservation of the organic matter produced at that time. Undoubtedly, the TOC and sums of biomarkers from the laminated marls show enhanced preservation during times of increased organic matter production, controlled by the oxygen depletion in the bottom waters and by the high activity of methanotrophic and methanogenic archaea.

Two deviations from the generally covarying trends in the TOC and biomarkers are observable. One, located at the top, is the low in alkenone production and/or preservation, while the sterols, archaeol, and long-chain $n$-alkanes are at their high. The explanation could be that the conditions were not favorable to alkenone production because of changes in the water column making the conditions unsuitable for alkenone-producers growth. The alkenones are very resistant biomarkers in geological record, and their oxidation is unlikely. Alternatively, they could not be observed in the $a$-polar fraction because of possible sulfurization of the organic matter under anoxic and heavily stratified conditions in the water column (Sinninghe Damsté et al., 1995). The second deviation from the covariance is observed in the sum of $C_{27}$ to $C_{33} n$-alkanes where the concentration is increasing five times from the preslump interval to postslump interval. The much increased amount of terrestrial organic matter at the time of increased accumulation rate (Figures 3 and 4) is hypothetically associated with the reconnection of the Mediterranean with the Paratethys, leading to increased stratification and finally to the MSC onset.

\subsubsection{TOC and Sedimentation Rate}

TOC content in sedimentary rocks is a function of (1) the organic carbon flux form aquatic and terrestrial sources and (2) preservation process controlled by the oxidation in the water column, during deposition and/or diagenesis (Calvert \& Pedersen, 2007). Poorly oxygenated bottom waters favor the preservation of the organic carbon. Consequently, the TOC content is high even when the flux of the organic carbon (from both aquatic and terrestrial sources) is low (Rohling et al., 2015). In this case, the preservation of the organic carbon is favored by high accumulation rates due to shorter exposure to oxygen.

In Kalamaki section the sedimentation rate varies significantly indicating that the TOC content could have been influenced by changes in accumulation rate. Based on the calculated sedimentation rates and 
previously published data, we divide the section into three main intervals: (1) 0 to $9 \mathrm{~m}$ (6.457-6.128 Ma), (2) 9 to $14.7 \mathrm{~m}(6.128-6.01 \mathrm{Ma})$, and (3) 14.7 to $22.11 \mathrm{~m}(6.01-5.971 \mathrm{Ma})$.

5.6.2.1. Toc and Biomarkers in Between 0 and $9 \mathrm{~m} \mathrm{(6.457-6.128} \mathrm{Ma)}$

Despite lower sedimentation rates, the TOC content was high, indicating elevated flux of organic carbon between 6.457 and 6.128 Ma. The generally high TOC content (seemingly fluctuating along unidentified periodical cycles; Figure 5) was favored by high productivity in the water column (Figure 8b), inference supported by high amounts of alkenones, sterols, and archaeol (Figure 5). The long chain $n$-alkanes amounts for this interval are two times smaller when compare to the upper part of the section (Figure 5). Therefore, we can argue that between 6.457 and 6.128 Ma, the productivity within the water column was relatively high. This conclusion is supported by Helicosphaera carteri, Calcidiscus leptoporus, Umbilicosphaera jafari, Reticulofenestra haqii, and $R$. minutula nannofossils assemblage, mostly represented by whole coccospheres, indicating high productivity and freshwater input to the surface waters (e.g., Triantaphyllou et al., 2009). At $0.8 \mathrm{~m}$ (6.424 Ma), a first low appearing simultaneously in TOC and quantified biomarkers suggests oxygenated conditions in the water column marked by the deposition of massive marl (Figure 8b). The low TOC values between 7 and $9 \mathrm{~m}$ (6.2 to $6.128 \mathrm{Ma}$ ) coincides with simultaneous low peaks in the biomarkers amounts. The coexistence of these lows suggests oxygenated conditions in the water column marked by distinct deposition of calcareous marl (Figure 8e). This assumption is supported by the presence of impressive monospecific assemblages of Sphenolithus abies (Karakitsios, Cornée, et al., 2017, Karakitsios, Roveri, et al., 2017), suggesting marine mesotrophic environments (Wade \& Bown, 2006). This S. abies event was coevally observed in other Messinian sites (Cyprus, Kouwenhoven \& van der Zwaan, 2006; Piedmont, Lozar et al., 2010; and north-eastern Apennine, Manzi et al., 2007).

5.6.2.2. TOC and Biomarkers in Between 9 and $14.7 \mathrm{~m}$ (6.128-6.01 Ma)

This second interval is characterized by higher but less fluctuating TOC content than the underlying 0 to $9 \mathrm{~m}$ (6.457-6.128 Ma). The relatively high TOC content was favored by high productivity in the water column, as indicated by high amounts of quantified biomarkers (Figure 5). In this interval important is the dominance of $O$. universa, foraminifera known to proliferate in mixed-layer surface waters during surfacewater stratification (Sierro et al., 2003). During the deposition of the interval between 9 and $14.3 \mathrm{~m}$ (6.128-6.01 Ma), the productivity within the water column was high while the organic carbon preservation must have been more efficient favored by the significantly amplified sedimentation rate from 28 to $44.5 \mathrm{~cm} / \mathrm{kyr}$ (Figure 8c) and the prevailing stratification in the water column. Additionally, higher sedimentation rate could have diluted the TOC into a larger amount of detrital material from the continent. The influx of Mediterranean marine waters in Paratethys at the Pontian transgression could have caused, next to the African rivers, an increased freshwater supply into the Mediterranean Sea and, consequently, increased nutrient levels (Figure 8f). Close to the top of this interval, at $13 \mathrm{~m}$, there is a low peak in TOC, sterols, archaeol, and long chain $n$-alkanes, retrieved from distinct calcareous marl. This short interval, at $13 \mathrm{~m}$ (6.025 Ma), likely marks another moment of oxygenation in the water column, similar to the situation illustrated in Figure 8d.

5.6.2.3. TOC and Biomarkers in Between 14.3 and $22.11 \mathrm{~m}$ (6.01-5.971 Ma)

The third interval, between 14.3 and $22.11 \mathrm{~m}$ (6.01-5.971 Ma), is characterized by the lowest TOC values, displaying very little variation. In this interval, the much increased sedimentation rate must have induced a dilution effect of the deposited organic matter. Increased sedimentation rate would also imply an increased input of terrestrially derived biomarkers (e.g., long chain $n$-alkanes). We observe indeed a more than five times increase in the long-chain $n$-alkanes. This interval shows a general decrease in alkenone amounts but high amounts of sterols, diols, and ketols, as well of archaeol. In this interval, the much increased sedimentation rate generated an increased preservation of the aquatic produced organic carbon and of the supplemented terrestrial, long-chain $n$-alkanes. Elevated productivity rates have been probably triggered by increased freshwater supply from both the Nile River (Figure 8c) and, highly-likely, Paratethys too (Figure 8f). In this interval, the only foraminifera left are O. universa, thriving in mixed-layer surface waters during surface-water stratification. The composition patterns of primary producers must have suffered compositional change, as indicated by low in alkenones close to the MSC onset, while stratification in the water column increased until it reached the deposition of the first gypsum layer of the MSC in Kalamaki (Figure 5). The onset of the MSC is marked by the disappearance of plankton assemblages as the Mediterranean Sea environment became unfavorable for eukaryotic life. 


\section{Conclusions}

The presented biomarker study in conjunction with earlier produced biostratigraphy data for the pre-MSC Kalamaki section are converging toward the insight that large environmental changes affected the pre-MSC Mediterranean Sea. We show that

1. Between 6.415 and $6.151 \mathrm{Ma}$ the Mediterranean Sea was colder and saltier $\left(\sim 22.9^{\circ} \mathrm{C}\right.$ and $47 \%$, respectively) than between 6.120 and $5.971 \mathrm{Ma}\left(24.1^{\circ} \mathrm{C}\right.$ and $39 \%$ ). The calculated salinity values are in line with recent experiments indicating That during the prerestriction phase, the box model estimates Mediterranean salinity is slightly higher than (37.6-38.2 g/L), but close to the prescribed Atlantic salinity of $36.5 \mathrm{~g} / \mathrm{L}$ (Simon et al., 2017). Whereas elevated salinity may be intermittent at the sea surface, it could have been permanent in the bottom waters some $100 \mathrm{kyr}$ before onset of the MSC.

2. The salinity decrease at 6.151 Ma seems to be a relatively fast event just preceding the inception of warming phase that lasted almost uninterrupted until the onset of MSC.

3. The changes in water SST determine a sharp drop in productivity and/or preservation of the organic matter, marked lithologically by calcareous marls. The calcareous marls mark moments of complete overturn in the water column provoked by large changes in the Mediterranean water budget.

4. In between the calcareous marls both the productivity and preservation were relatively high and constant until the 6.01 Ma. The productivity however was higher during warmer phases; increased productivity was expected, expressed slightly higher amounts of biomarkers. After 6.01 Ma increased terrestrial organic matter influx, and enhanced stratification in the water column, prevailed. At the top, around 5.971 Ma, compositional modifications in aquatic versus terrestrially derived biomarkers indicate a change of the organic matter source.

5. The influx of Mediterranean waters in Paratethys seen as marine fauna at the Pontian transgression could have caused, next to the African rivers, an increased freshwater supply into the Mediterranean Sea. The cumulative effect of African river runoff and Paratethys influx is the most likely mechanism of freshening of Mediterranean water, making it normal marine for the interval between 6.151 and $5.971 \mathrm{Ma}$.

\section{Acknowledgments}

This research has been cofinanced by the European Union (European Social Fund-ESF) and Greek national funds through the Operational Program "Education and Lifelong Learning" of the National Strategic Reference Framework (NSRF) - Research Funding Program: THALISUOA-"Messinian Salinity Crisis: the greatest Mediterranean environmental perturbation and its repercussions to the biota" (MEDSALC) MIS: 375405. Collaboration was also possible through the COST Action CA15103

"Uncovering the Mediterranean salt giant" (MEDSALT) supported by COST (European Cooperation in Science and Technology). The data are stored in PANGAEA database (www.pangaea. de). We thank all four anonymous reviews for constructive comments that significantly improved the manuscript.

\section{References}

Achalhi, M., Münch, P., Cornée, J. J., Azdimousa, A., Melinte-Dobrinescu, M. C., Quillévéré, F., et al. (2016). The late Miocene Mediterranean-Atlantic connections through the North Rifian Corridor: New insights from the Boudinar and Arbaa Taourirt basins (northeastern Rif, Morocco). Palaeogeography, Palaeoclimatology, Palaeoecology, 459, 131-152. https://doi.org/10.1016/j. palaeo.2016.06.040

Andersen, N., Paul, H. A., Bernasconi, S. M., McKenzie, J. A., Behrens, A., Schaeffer, P., \& Albrecht, P. (2001). Large and rapid climate variability during the Messinian Salinity Crisis: Evidence from deuterium concentrations of individual biomarkers. Geology, 29(9), 799-802. https://doi.org/10.1130/0091-7613(2001)029<0799:LARCVD>2.0.CO;2

Antonarakou, A., Kontakiotis, G., Mortyn, P. G., Drinia, H., Sprovieri, M., Besiou, E., \& Tripsanas, E. (2015). Biotic and geochemical ( $\delta^{18}$ O, $\delta^{13} \mathrm{C}, \mathrm{Mg} / \mathrm{Ca}, \mathrm{Ba} / \mathrm{Ca}$ ) responses of Globigerinoides ruber morphotypes to upper water column variations during the last deglaciation, Gulf of Mexico. Geochimica et Cosmochimica Acta, 170, 69-93. https://doi.org/10.1016/j.gca.2015.08.003

Antonarakou, A., Kontakiotis, G., Vasilatos, C., Besiou, E., Zarkogiannis, S., Drinia, H., et al. (2018). Evaluating the effect of marine diagenesis on Late Miocene pre-evaporitic sedimentary successions of eastern Mediterranean Sea. Grande-Bretagne: IOP: Earth \& Environmental Sciences.

Antonarakou, A., Kontakiotis, G., Zarkogiannis, S., Mortyn, P. G., Drinia, H., Koskeridou, E., \& Anastasakis, G. (2018). Planktonic foraminiferal abnormalities in coastal and open marine eastern Mediterranean environments: A natural stress monitoring approach in recent and early Holocene marine systems. Journal of Marine Systems, 181, 63-78. https://doi.org/10.1016/j.jmarsys.2018.02.004

Athanasiou, M., Bouloubassi, I., Gogou, A., Klein, V., Dimiza, M. D., Parinos, C., et al. (2017). Sea surface temperatures and environmental conditions during the "warm Pliocene" interval ( 4.1-3.2 Ma) in the Eastern Mediterranean (Cyprus). Global and Planetary Change, 150, 46-57. https://doi.org/10.1016/j.gloplacha.2017.01.008

Bé, A. W. H., \& Duplessy, J.-C. (1976). Subtropical convergence fluctuations and Quaternary climates in the middle latitudes of the Indian Ocean. Science, 194(4263), 419-422. https://doi.org/10.1126/science.194.4263.419

Bellanca, A., Caruso, A., Ferruzza, G., Neri, R., Rouchy, J. M., Sprovieri, M., \& Blanc-Valleron, M. M. (2001). Transition from marine to hypersaline conditions in the Messinian Tripoli Formation from the marginal areas of the central Sicilian Basin. Sedimentary Geology, 140(1-2), 87-105. https://doi.org/10.1016/S0037-0738(00)00173-1

Beltran, C., de Rafélis, M., Minoletti, F., Renard, M., Sicre, M. A., \& Ezat, U. (2007). Coccolith $\delta 180$ and alkenone records in middle Pliocene orbitally controlled deposits: high frequency temperature and salinity variations of sea surface water. Geochemistry, Geophysics, Geosystems, 8, Q05003. https://doi.org/10.1029/2006GC001483

Beltran, C., Flores, J. A., Sicre, M. A., Baudin, F., Renard, M., \& de Rafélis, M. (2011). Long chain alkenones in the early Pliocene Sicilian sediments (Trubi Formation-Punta di Maiata section): Implications for the alkenone paleothermometry. Palaeogeography, Palaeoclimatology, Palaeoecology, 308(3-4), 253-263. https://doi.org/10.1016/j.palaeo.2011.03.017

Bemis, B. E., Spero, H. J., Bijma, J., \& Lea, D. W. (1998). Reevaluation of the oxygen isotopic composition of planktonic foraminifera: Experimental results and revised paleotemperature equations. Paleoceanography, 13(2), 150-160. https://doi.org/10.1029/98PA00070 
Bijma, J., Faberand, W. W., \& Hemleben, C. (1990). Temperature and salinity limits for growth and survival of some planktonic foraminifers in laboratory cultures. Journal of Foraminiferal Research, 20(2), 95-116. https://doi.org/10.2113/gsjfr.20.2.95

Birgel, D., Himmler, T., Freiwald, A., \& Peckmann, J. (2008). A new constraint on the antiquity of anaerobic oxidation of methane: Late Pennsylvanian seep limestones from southern Namibia. Geology, 36(7), 543-546. https://doi.org/10.1130/G24690A.1

Blanc-Valleron, M.-M., Pierre, C., Caulet, J. P., Caruso, A., Rouchy, J.-M., Cespuglio, G., et al. (2002). Sedimentary, stable isotope and micropaleontological records of paleoceanographic change in the Messinian Tripoli Formation (Sicily, Italy). Palaeogeography, Palaeoclimatology, Palaeoecology, 185(3-4), 255-286. https://doi.org/10.1016/S0031-0182(02)00302-4

Brachert, T. C., Bornemann, A., Reuter, M., Galer, S. J., Grimm, K. I., \& Fassoulas, C. (2015). Upwelling history of the Mediterranean Sea revealed by stunted growth in the planktic foraminifera Orbulina universa (early Messinian, Crete, Greece). International Journal of Earth Sciences, 104(1), 263-276. https://doi.org/10.1007/s00531-014-1076-8

Bray, E. E., \& Evans, E. D. (1961). Distribution of normal-paraffins as a clue to recognition of source beds. Geochimica et Cosmochimica Acta, 22(1), 2-15. https://doi.org/10.1016/0016-7037(61)90069-2

Calvert, S. E., \& Pedersen, T. F. (2007). Elemental proxies for palaeoclimatic and palaeoceanographic variability in marine sediments: Interpretation and application. In C. Hillaire-Marcel \& A. D. Vernal (Eds.), Proxies in Late Cenozoic Paleoceanography (pp. 567-644). Amsterdam: Elsevier. https://doi.org/10.1016/S1572-5480(07)01019-6

Chu, G., Sun, Q., Li, S., Zheng, M., Jia, X., Lu, C., Liu, J., et al. (2005). Long-chain alkenone distributions and temperature dependence in lacustrine surface sediments from China. Geochimica et Cosmochimica Acta, 69, 4985-5003.

Cita, M. B. (1976). Planktonic foraminiferal biostratigraphy of the Mediterranean Neogene. In Progr. in Micropaleont (pp. 47-68). New York: Micropaleontology Press.

Conte, M. H., Thompson, A., Lesley, D., \& Harris, R. P. (1998). Genetic and physiological influences on the alkenone/alkenoate versus growth temperature relationship in Emiliania huxleyi and Gephyrocapsa Oceanica. Geochimica et Cosmochimica Acta, 62(1), 51-68. https://doi.org/10.1016/S0016-7037(97)00327-X

de Leeuw, J. W., Rijpstra, W. I. C., \& Schenck, P. A. (1981). The occurrence and identification of C30,C31 and C32 alkan 1,15-diols and alkan 15-one 1-ols in Unit I and Unit II Black Sea sediments. Geochimica et Cosmochimica Acta, 45, 2281-2285.

Drinia, H., Antonarakou, A., Tsaparas, N., \& Kontakiotis, G. (2007). Palaeoenvironmental conditions preceding the Messinian Salinity Crisis: A case study from Gavdos Island. Geobios, 40(3), 251-265. https://doi.org/10.1016/j.geobios.2007.02.003

Eglinton, G., \& Hamilton, R. J. (1967). Leaf Epicular waxes. Science, 156(3780), 1322-1335. https://doi.org/10.1126/ science.156.3780.1322

Emeis, K. C., Struck, U., Schulz, H. M., Rosenberg, R., Bernasconi, S., Erlenkeuser, H., et al. (2000). Temperature and salinity variations of Mediterranean Sea surface waters over the last 16,000 years from records of planktonic stable oxygen isotopes and alkenone unsaturation ratios. Palaeogeography, Palaeoclimatology, Palaeoecology, 158(3-4), 259-280. https://doi.org/10.1016/S0031-0182(00)00053-5

Erez, J., \& Luz, B. (1983). Experimental paleotemperature equation for planktonic foraminifera. Geochimica et Cosmochimica Acta, 47(6), 1025-1031. https://doi.org/10.1016/0016-7037(83)90232-6

Farmer, E. C., Kaplan, A., de Menocal, P. B., \& Lynch-Stieglitz, J. (2007). Corroborating ecological depth preferences of planktonic foraminifera in the tropical Atlantic with the stable oxygen isotope ratios of core top specimens. Paleoceanography, 22, PA3205. https://doi. org/10.1029/2006PA001361

Fenton, M., Geiselhart, S., Rohling, E. J., \& Hemleben, C. (2000). Aplanktonic zones in the Red Sea. Marine Micropaleontology, 40(3), 277-294. https://doi.org/10.1016/S0377-8398(00)00042-6

Flecker, R., Krijgsman, W., Capella, W., de Castro Martíns, C., Dmitrieva, E., Mayser, J. P., et al. (2015). Evolution of the Late Miocene Mediterranean Atlantic gateways and their impact on regional and global environmental change. Earth Science Reviews, 150, 365-392. https://doi.org/10.1016/j.earscirev.2015.08.007

Furota, S., Nakamura, H., \& Sawada, K. (2016). Long-chain alkenones and related distinctive compounds in the late Miocene and Pliocene sediments from the Gulf of Cadiz, eastern North Atlantic. Organic Geochemistry, 101, 166-175. https://doi.org/10.1016/j. orggeochem.2016.08.014

Gennari, G., Lozar, F., Turco, E., Dela Pierre, F., Manzi, V., Natalicchio, M., et al. (2018). Integrated stratigraphy and paleo-ceanographic evolution of the pre-evaporitic phase of the Messinian Salinity Crisis in the Eastern Mediterranean as recorded in the Tokhni section (Cyprus). Newsletters on Stratigraphy, 51(1), 33-55. https://doi.org/10.1127/nos/2017/0350

Grothe, A., Sangiorgi, F., Brinkhuis, H., Stoica, M., \& Krijgsman, W. (2018). Migration of the dinoflagellate Galeacysta etrusca and its implications for the Messinian Salinity Crisis. Newsletters on Stratigraphy, 51(1), 73-91. https://doi.org/10.1127/nos/2016/0340

Haenel, P. (1987). Intérêt paléoocéanographique d'Orbulina universa d'Orbigny (foraminifère). Oceanologica Acta, $10,15-25$.

Herbert, T. D., Lawrence, K. T., Tzanova, A., Cleaveland-Peterson, L., Gabalero-Gill, R., \& Kelly, K. S. (2016). Late Miocene global cooling and the rise of modern ecosystems. Nature Geoscience, 9(11), 843-847. https://doi.org/10.1038/ngeo2813

Herbert, T. D., Ng, G., \& Peterson, L. C. (2015). Evolution of Mediterranean Sea surface temperatures 3.5-1.5 Ma: Regional and hemispheric influences. Earth and Planetary Science Letters, 409, 307-318. https://doi.org/10.1016/j.epsl.2014.10.006

Ivanovic, R. F., Flecker, R., Gutjahr, M., \& Valdes, P. J. (2013). First Nd isotope record of Mediterranean-Atlantic water exchange through the Moroccan Rifian Corridor during the Messinian Salinity Crisis. Earth and Planetary Science, 368, 163-174.

Ivanovic, R. F., Valdes, P. J., Flecker, R., \& Gutjahr, M. (2014). Modelling global-scale climate impacts of the late Miocene Messinian Salinity Crisis. Climate of the Past, 10, 607-622.

Kallel, N., Paterne, M., Labeyrie, L. D., Duplessy, J. C., \& Arnold, M. (1997). Temperature and salinity records of the Tyrrhenian Sea during the last 18000 years. Palaeogeography, Palaeoclimatology, Palaeoecology, 135(1-4), 97-108. https://doi.org/10.1016/S00310182(97)00021-7

Karakitsios, V., Cornée, J.-J., Tsourou, T., Moissette, P., Kontakiotis, G., Agiadi, K., Manoutsoglou, E., et al. (2017). Messinian Salinity Crisis record under strong freshwater input in marginal, intermediate, and deep environments: The case of the North Aegean. Palaeogeography Palaeoclimatology Palaeoecology, 485, 316-335. https://doi.org/10.1016/j.palaeo.2017.06.023

Karakitsios, V., Roveri, M., Lugli, S., Manzi, V., Gennari, G., Antonarakou, A., et al. (2017). A record of the Messinian Salinity Crisis in the eastern Ionian tectonically active domain (Greece, eastern Mediterranean). Basin Research, 29(2), 203-233. https://doi.org/10.1111/bre.12173

Kontakiotis, G., Antonarakou, A., Mortyn, P. G., Drinia, H., Anastasakis, G., Zarkogiannis, S., \& Mobius, J. (2017). Morphological recognition of Globigerinoides ruber morphotypes and their susceptibility to diagenetic alteration in the eastern Mediterranean Sea. Journal of Marine Systems, 174, 12-24. https://doi.org/10.1016/j.jmarsys.2017.05.005

Kontakiotis, G., Karakitsios, V., Mortyn, P. G., Antonarakou, A., Drinia, H., Anastasakis, G., et al. (2016). New insights into the early Pliocene hydrographic dynamics and their relationship to the climatic evolution of the Mediterranean Sea. Palaeogeography, Palaeoclimatology, Palaeoecology, 459, 348-364. https://doi.org/10.1016/j.palaeo.2016.07.025 
Kontakiotis, G., Mortyn, G. P., Antonarakou, A., \& Drinia, H. (2016). Assessing the reliability of foraminiferal mg/ca thermometry by comparing field-samples and culture experiments: A review. Geological Quarterly, 60(3), 547-560.

Kontakiotis, G., Mortyn, P. G., Antonarakou, A., Martínez-Botí, M. À., \& Triantaphyllou, M. V. (2011). Field-based validation of a diagenetic effect on G. ruber $\mathrm{Mg} / \mathrm{Ca}$ paleothermometry: Core top results from the Aegean Sea (eastern Mediterranean). Geochemistry, Geophysics, Geosystems, 12, Q09004. https://doi.org/10.1029/2011GC003692

Kouwenhoven, T. J., Hilgen, F. J., \& van der Zwaan, G. J. (2003). Late Tortonian-early Messinian stepwise disruption of the MediterraneanAtlantic connections: Constraints from benthic foraminiferal and geochemical data. Palaeogeography, Palaeoclimatology, Palaeoecology, 198(3-4), 303-319. https://doi.org/10.1016/S0031-0182(03)00472-3

Kouwenhoven, T. J., \& van der Zwaan, G. J. (2006). A reconstruction of late Miocene Mediterranean circulation patterns using benthic foraminifera. Palaeogeography, Palaeoclimatology, Palaeoecology, 238(1-4), 373-385. https://doi.org/10.1016/j.palaeo.2006.03.035

Krijgsman, W., Hilgen, F. J., Raffi, I., Sierro, F. J., \& Wilson, D. S. (1999). Chronology, causes and progression of the Messinian Salinity Crisis. Nature, 400(6745), 652-655. https://doi.org/10.1038/23231

Krijgsman, W., Stoica, M., Vasiliev, I., \& Popov, V. V. (2010). Rise and fall of the Paratethys Sea during the Messinian Salinity Crisis. Earth and Planetary Science Letters, 290(1-2), 183-191. https://doi.org/10.1016/j.epsl.2009.12.020

Lafargue, E., Marquis, F. D., \& Daniel, P. (1998). Rock-Eval 6 applications in hydrocarbon exploration, production, and soil contamination studies. Oil \& Gas Science and Technology revue De L'Institut Francais Du Petrole. Oil \& Gas Science and Technology, 53, $421-437$. https://doi.org/10.2516/ogst:1998036

Laskar, J., Roubutel, P., Joutel, F., Gaastineau, M., Correia, A., \& Levrard, B. (2004). A long-term numerical solution for the insolation quantities of the earth. Astronomy and Astrophysics, 428(1), 261-285. https://doi.org/10.1051/0004-6361:20041335

Li, J., Pancost, R. D., Naafs, B. D. A., Yang, H., Zhao, C., \& Xie, S. (2016). Distribution of glycerol dialkyl glycerol tetraether (GDGT) lipids in a hypersaline lake system. Organic Geochemistry, 99, 113-124. https://doi.org/10.1016/j.orggeochem.2016.06.007

Lincoln, S. A., Wai, B., Eppley, J. M., Church, M. J., Summons, R. E., \& DeLong, E. F. (2014). Planktonic Euryarchaeota are a significant source of archaeal tetraether lipids in the ocean. Proceedings of the National Academy of Sciences of the United States of America, 111(27), 9858-9863. https://doi.org/10.1073/pnas.1409439111

Lourens, L. J., Hilgen, F. J., Laskar, J., Shackleton, N. J., \& Wilson, D. S. (2004). The Neogene Period. In F. Gradstein, J. Ogg, \& A. Smith (Eds.), A geological timescale 2004 (pp. 409-440). Cambridge: Cambridge University Press.

Lozar, F., Violanti, D., Pierre, F. D., Bernardi, E., Cavagna, S., Clari, P., et al. (2010). Calcareous nannofossils and foraminifers Herald the Messinian Salinity Crisis: The Pollenzo section (Alba, Cuneo; NW Italy). Geobios, 43(1), 21-32. https://doi.org/10.1016/j.geobios.2009.07.002

Manzi, V., Gennari, R., Hilgen, F., Krijgsman, W., Lugli, S., Roveri, M., \& Sierro, F. J. (2013). Age refinement of the Messinian Salinity Crisis onset in the Mediterranean. Terra Nova, 25(4), 315-322. https://doi.org/10.1111/ter.12038

Manzi, V., Gennari, R., Lugli, S., Persico, D., Reghizzi, M., Roveri, M., et al. (2018). The onset of the Messinian Salinity Crisis in the deep Eastern Mediterranean basin. Terra Nova, 30(3), 189-198. https://doi.org/10.1111/ter.12325

Manzi, V., Roveri, M., Gennari, R., Bertini, A., Biffi, U., Giunta, S., et al. (2007). The deep-water counterpart of the Messinian lower evaporites in the Apennine foredeep: The Fanantello section (Northern Apennines, Italy). Palaeogeography Palaeoclimatology Palaeoecology, 251(3-4), 470-499. https://doi.org/10.1016/j.palaeo.2007.04.012

Marzocchi, A., Lunt, D. J., Flecker, R., Bradshaw, C. D., Farnsworth, A., \& Hilgen, F. J. (2015). Orbital control on late Miocene climate and the North African monsoon: Insight from an ensemble of sub-precessional simulations. Climate of the Past, 11(10), 1271-1295.

Mayser, J. P., Flecker, R., Marzzochi, A., Kouwvernhoven, T. J., Lunt, D. J., \& Pancost, R. D. (2017). Precession driven changes in terrestrial organic matter input to the Eastern Mediterranean leading up to the Messinian Salinity Crisis. Earth and Planetary Science Letters, 462, 199-211. https://doi.org/10.1016/j.epsl.2017.01.029

Meilijson, A., Steinberg, J., Hilgen, F., Bialik, O. M., Waldmann, N. D., \& Makovsky, Y. (2018). Deep-basin evidence resolves a 50-year-old debate and demonstrates synchronous onset of Messinian evaporite deposition in a non-desiccated Mediterranean. Geology, 46, 4-7.

Miller, K. G., Mountain, G. S., Wright, J. D., \& Browning, J. V. (2011). A 180-million-year record of sea level and ice volume variations from continental margin and deep-sea isotopic records. Oceanography, 24(2), 40-53. https://doi.org/10.5670/oceanog.2011.26

Moissette, P., Cornée, J. J., Antonarakou, A., Kontakiotis, G., Drinia, H., Koskeridou, E., et al. (2018). Palaeoenvironmental changes at the Tortonian/Messinian boundary: A deep-sea sedimentary record of the eastern Mediterranean Sea. Palaeogeography, Palaeoclimatology, Palaeoecology, 505, 217-233. https://doi.org/10.1016/j.palaeo.2018.05.046

Morard, R., Quillévéré, F., Escarguel, G., Ujiie, Y., de Garidel-Thoron, T., Norris, R. D., \& de Vargas, C. (2009). Morphological recognition of cryptic species in the planktonic foraminifer Orbulina universa. Marine Micropaleontology, 71(3-4), 148-165. https://doi.org/10.1016/j. marmicro.2009.03.001

Müller, P. J., Kirst, G., Ruhland, G., vonStorch, I., \& Rosell-Mele, A. (1998). Calibration of the alkenone paleotemperature index U-37(K') based on core-tops from the eastern South Atlantic and the global ocean $\left(60^{\circ} \mathrm{N}-60^{\circ} \mathrm{S}\right)$. Geochimica et Cosmochimica Acta, $62(10)$, 1757-1772. https://doi.org/10.1016/S0016-7037(98)00097-0

Natalicchio, M., Birgel, D., Peckmann, J., Lozar, F., Carnevale, G., Liu, X., et al. (2017). An archaeal biomarker record of paleoenvironmental change across the onset of the Messinian Salinity Crisis in the absence of evaporites (Piedmont Basin, Italy). Organic Geochemistry, 113, 242-253. https://doi.org/10.1016/j.orggeochem.2017.08.014

Ortiz, J. D., Mix, A. C., Rugh, W., Watkins, J. M., \& Collier, R. W. (1996). Deep-dwelling planktonic foraminifera of the northeastern Pacific Ocean reveal environmental control of oxygen and carbon isotope disequilibria. Geochimica et Cosmochimica Acta, 60(22), 4509-4523. https://doi.org/10.1016/S0016-7037(96)00256-6

Pados, T., Spielhagen, R. F., Bauch, D., Meyer, H., \& Segl, M. (2015). Oxygen and carbon isotope composition of modern planktic foraminifera and near-surface waters in the Fram Strait (Arctic Ocean)—A case study. Biogeosciences, 12(6), 1733-1752. https://doi.org/ $10.5194 /$ bg-12-1733-2015

Popov, S. V., Shcherba, I. G., Ilyina, L. B., Nevesskaya, L. A., Paramonova, N. P., Khondkarian, S. O., \& Magyar, I. (2006). Late Miocene to Pliocene palaeogeography of the Paratethys and its relation to the Mediterranean. Palaeogeography, Palaeoclimatology, Palaeoecology, 238, 91-106. https://doi.org/10.1016/j.pa laeo.2006.03.020

Poynter, J., \& Eglinton, G. (1990). Molecular composition of three sediments from hole 717C: The Bengal Fan. In J. R. Cochran, D. A. V. Stow, et al. (Eds.), Proc. ODP, Sci. Results (Vol. 116, pp. 155-161). College Station, TX: Ocean Drilling Program.

Prahl, F. G., Cowie, G. L., de Lange, G. J., \& Sparrow, M. A. (2003). Selective organic matter preservation in "burn-down” turbidites on the Madeira Abyssal Plain. Paleoceanography, 18(2), 1052. https://doi.org/10.1029/2002PA000853

Rampen, S. W., Schouten, S., Koning, E., Brummer, G.-J. A., \& Sinninghe Damsté, J. S. (2008). A 90 kyr upwelling record from the northwestern Indian Ocean using a novel long-chain diol index. Earth and Planetary Science Letters, 276(1-2), 207-213. https://doi.org/ 10.1016/j.epsl.2008.09.022 
Rohling, E. J. (2007). Progress in paleosalinity: Overview and presentation of a new approach. Paleoceanography, 22, PA3215. https://doi. org/10.1029/2007PA001437

Rohling, E. J., Marino, G., \& Grant, K. M. (2015). Mediterranean climate and oceanography and the periodic development of anoxic events (sapropels). Earth Science Reviews, 143, 62-97. https://doi.org/10.1016/j.earscirev.2015.01.008

Rohling, E. J., Sprovieri, M., Cane, T., Casford, J. S. L., Cooke, S., Bouloubassi, I., et al. (2004). Reconstructing past planktic foraminiferal habitats using stable isotope data: A case history for Mediterranean sapropel S5. Marine Micropaleontology, 50(1-2), 89-123. https://doi. org/10.1016/S0377-8398(03)00068-9

Roveri, M., Flecker, R., Krijgsman, W., Lofi, J., Lugli, S., Manzi, V., et al. (2014). The Messinian Salinity Crisis: Past and future of a great challenge for marine sciences. Marine Geology, 352, 25-58. https://doi.org/10.1016/j.margeo.2014.02.002

Ryan, W. B. F. (2009). Decoding the Messinian Salinity Crisis. Sedimentology, 56(1), 95-136. https://doi.org/10.1111/j.13653091.2008.01031.x

Santarelli, A., Brinkhuis, H., Hilgen, F. J., Lourens, L. J., \& Versteegh, G. J. M. (1998). Orbital signatures in a late Miocene dinoflagellate record from Crete (Greece). Marine Micropaleontology, 33(3-4), 273-297. https://doi.org/10.1016/S0377-8398(97)00042-X

Schmidt, G. A. (1999). Error analysis of paleosalinity calculations. Paleoceanography, 14(3), 422-429. https://doi.org/10.1029/ 1999PA900008

Schmidt, M. W., \& Lynch-Stieglitz, J. (2011). Florida straits deglacial temperature and salinity change: Implications for tropical hydrologic cycle variability during the Younger Dryas. Paleoceanography, 26, PA4205. https://doi.org/10.1029/21011PA002157

Schouten, S., Hopmans, E. C., \& Sinninghe Damste' J. S. (2013). The organic geochemistry of glycerol dialkyl glycerol tetraether lipids: A review. Organic Geochemistry, 54, 19-61. https://doi.org/10.1016/j.orggeochem.2012.09.006

Schrag, D. P., Berner, R. A., Hoffman, P. F., \& Halverson, G. P. (2002). On the initiation of a snowball Earth. Geochemistry, Geophysics, Geosystems, 3(6), 1036. https://doi.org/10.1029/2001GC000219

Selli, R. (1960). Il Messiniano Mayer-Eymar 1867. Proposta di un neostratotipo. Giornale di Geologia, 28, 1-33.

Sierro, F. J., Flores, J. A., Frances, G., Vazquez, A., Utrilla, R., Zamarreno, I., et al. (2003). Orbitally-controlled oscillations in planktic communities and cyclic changes in western Mediterranean hydrog-raphy during the Messinian. Palaeogeography, Palaeoclimatology, Palaeoecology, 190, 289-316. https://doi.org/10.1016/S0031-0182(02)00611-9

Simon, D., Marzocchi, A., Flecker, R., Lunt, D., Hilgen, F., \& Meijer, P. (2017). Quantifying the Mediterranean freshwater budget throughout the late salinity crisis. Earth and Planetary Science Letters, 472, 25-37. https://doi.org/10.1016/j.epsl.2017.05.013

Simon, D., \& Meijer, P. (2017). Salinity stratification of the Mediterranean Sea during the Messinian crisis: A first model analysis. Earth and Planetary Science Letters, 472, 25-37. https://doi.org/10.1016/j.epsl.2017.05.013

Simstich, J., Sarnthein, M., \& Erlenkeuser, H. (2003). Paired ${ }^{18} \mathrm{O}$ signals of Neogloboquadrina pachyderma (s) and Turborotalita quinqueloba show thermal stratification structure in the Nordic seas. Marine Micropaleontology, 48(1-2), 107-125. https://doi.org/10.1016/ S0377-8398(02)00165-2

Sinninghe Damsté, J. S., Kenig, F., Koopmans, M. P., Köster, J., Schouten, S., Hayes, J. M., \& de Leeuw, J. W. (1995). Evidence for gammacerane as an indicator of water column stratification. Geochimica et Cosmochimica Acta, 59(9), 1895-1900. https://doi.org/10.1016/ 0016-7037(95)00073-9

Spero, H. J., \& Lea, D. W. (1996). Experimental determination of stable isotope variability in Globigerina bulloides: Implications for paleoceanographic reconstruction. Marine Micropaleontology, 28(3-4), 231-246. https://doi.org/10.1016/0377-8398(96)00003-5

Triantaphyllou, M. V., Ziveri, P., Gogou, A., Marino, G., Lykousis, V., Bouloubassi, I., et al. (2009). Late Glacial-Holocene climate variability at the south-eastern margin of the Aegean Sea. Marine Geology, 266(1-4), 182-197. https://doi.org/10.1016/j.margeo.2009.08.005

Tulbure, M. A., Capella, W., Barhoun, N., Flores, J. A., Hilgen, F. J., Krijgsman, W., et al. (2017). Age refinement and basin evolu-tion of the North Rifian Corridor (Morocco): No evidence for a marine connection during the Messinian Salinity Crisis. Palaeogeography, Palaeoclimatology, Palaeoecology, 485, 416-432. https://doi.org/10.1016/j.palaeo.2017.06.031

Tzanova, A. (2015). Linking late Miocene-Pliocene sea surface temperatures, terrestrial biome transitions and intensification of glaciation using alkenone paleothermometry, (PhD thesis). Columbia University, New York.

Tzanova, A., Herbert, T. D., \& Peterson, L. (2015). Cooling Mediterranean Sea surface temperatures during the Late Miocene provide a climate context for evolu-tionary transitions in Africa and Eurasia. Earth and Planetary Science Letters, 419, 71-80. https://doi.org/ 10.1016/j.epsl.2015.03.016

Underhill, J. R. (1989). Late Cenozoic deformation of the Hellenide foreland, western Greece. GSA Bulletin, 101(5), 613-634. https://doi. org/10.1130/0016-7606(1989)101<0613:LCDOTH>2.3.CO;2

Van der Laan, E., Gaboardi, S., Hilgen, F. J., \& Lourens, L. J. (2005). Regional climate and glacial control on high-resolution oxygen isotope records from Ain el Beida (latest Miocene, Northwest Morocco): A cyclostratigraphic analysis in the depth and time domain. Paleoceanography, 20, PA1001. https://doi.org/10.1029/2003PA000995

van der Meer, M. T. J., Baas, M., Rijpstra, I. C., Marino, G., Rohling, E. J., Sinninghe Damsté, J. S., \& Schouten, S. (2007). Hydrogen isotopic compositions of long-chain alkenones record freshwater flooding of the Eastern Mediterranean at the onset of sapropel deposition. Earth and Planetary Science Letters, 262(3-4), 594-600. https://doi.org/10.1016/j.epsl.2007.08.014

Vasiliev, I., Mezger, E. M., Lugli, S., Reichart, G. J., Manzi, V., \& Roveri, M. (2017). How dry was the Mediterranean during the Messinian Salinity Crisis? Palaeogeography, Palaeoclimatology, Palaeoecology, 471, 120-133. https://doi.org/10.1016/j.palaeo.2017.01.032

Volkman, J. K. (2003). Sterols in microorganisms. Applied Microbiology and Biotechnology, 60(5), 495-506. https://doi.org/10.1007/s00253$002-1172-8$

Volkman, J. K., Barrett, S. M., \& Blackburn, S. I. (1999). Eustigmatophyte microalgae are potential sources of C29 sterols, C22-C28 nalcohols and C28-C32 n-alkyl diols in freshwater environments. Organic Geochemistry, 30(5), 307-318. https://doi.org/10.1016/S01466380(99)00009-1

Volkman, J. K., Jeffrey, S. W., Nichols, P. D., Rogers, G. I., \& Garland, C. D. (1989). Fatty acid and lipid composition of 10 species of microalgae used in mariculture. Journal of Experimental Marine Biology and Ecology, 128, 219-240. https://doi.org/10.1016/00220981(89)90029-4

Volkmann, R., \& Mensch, M. (2001). Stable isotope composition $\left({ }^{18} \mathrm{O},{ }^{13} \mathrm{C}\right)$ of living planktic foraminifers in the outer Laptev Sea and the Fram Strait. Marine Micropaleontology, 42(3-4), 163-188. https://doi.org/10.1016/S0377-8398(01)00018-4

Wade, B. S., \& Bown, P. R. (2006). Calcareous nannofossils in extreme environments: The Messinian Salinity Crisis, Polemi Basin, Cyprus. Palaeogeography, Palaeoclimatology, Palaeoecology, 233(3-4), 271-286. https://doi.org/10.1016/j.palaeo.2005.10.007

Williams, M., Haywood, A. M., Taylor, S. P., Valdes, P. J., Sellwood, B. W., \& Hillenbrand, C. D. (2005). Evaluating the efficacy of planktonic foraminifer calcite delta O-18 data for sea surface temperature reconstruction for the Late Miocene. Geobios, 38(6), 843-863. https://doi. org/10.1016/j.geobios.2004.12.001 